

\section{A PRIMER ON WATER QUALITY}

H. A. Swenson

H. L. Baldwin

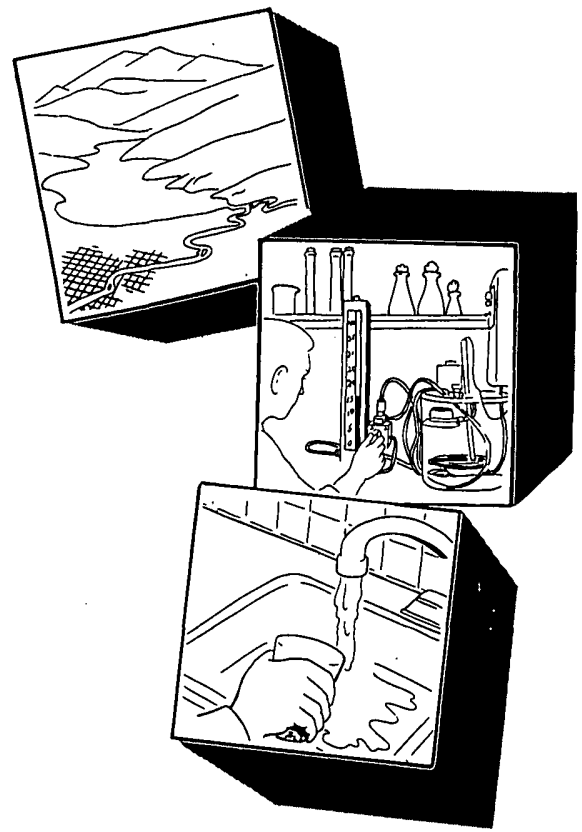


UNITED STATES DEPARTMENT OF THE INTERIOR

STEWART L. UDALL, Secretary

GEOLOGICAL SURVEY

William T. Pecora, Director

REPRINTED 1965 
CONTENTS

What "water quality" means . . . . . . . . . . . . . . . . . . . . .

Page

Water's structure and unusual properties . . . . . . . . . . . . . . .

How nature affects water quality . . . . . . . . . . . . . . . .

The water cycle.

Rivers carry salts and sediments . . . . . . . . . . . . . . . . . . . . 4

Ground water reacts with earth materials . . . . . . . . . . . . . 6

Man and his wastes. . . . . . . . . . . . . . . . . . 6

Wastes result from use . . . . . . . . . . . . . . . . . . . . . . . 8

Some waste-water problems . . . . . . . . . . . . . . . . . . . . 8

Characteristics of water . . . . . . . . . . . . . . . . . . . 11

Minerals in solution. . . . . . . . . . . . . . . . . . 14

Hardness and other properties . . . . . . . . . . . . . . . . 17

Biological considerations . . . . . . . . . . . . . . . . . . . . . . 19

Organics, dissolved gases, and sediment . . . . . . . . . . . . . . 20

Saline water . . . . . . . . . . . . . . . . . 20

Water demand and treatment . . . . . . . . . . . . . . . 22

Criteria for water quality . . . . . . . . . . . . . . . . . . . . 25

Water-quality management . . . . . . . . . . . . . . . . . 26

ORSANCO . . . . . . . . . . . . . . . . . . . 26

Desalinization . . . . . . . . . . . . . . . . . . . . . . 27

The need for research . . . . . . . . . . . . . . . . . . . . . . . . 27

Figure

\section{ILLUSTRATIONS}

1. How water quality is changed as water moves through the water cycle . . . . . . . . . . . . . . . . . . . . . . . . . . . . . 5

2. Some water-quality problems result from man's actions . . . . . . . . 7

3. Use of industrial water . . . . . . . . . . . . . . . . . . . . . . 11

4. Weighted average hardness, by States and Puerto Rico, of water delivered from 1,596 public supplies, 1962 . . . . . . . . . . . . . . . . . 12

5. Quality-of-water tolerances for certain industries . . . . . . . . . . . 18

6. Relation of fresh water to salt water . . . . . . . . . . . . . . . . 21

7. Water demand. . . . . . . . . . . . . . . . . . . . . 22

8. Quality control costs money . . . . . . . . . . . . . . . . . . . 24

9. Treatment of water . . . . . . . . . . . . . . . 25 


\title{
A PRIMER ON WATER QUALITY
}

\author{
H. A. Swenson and H. L. Baldwin
}

\section{WHAT "WATER QUALITY" MEANS}

Water from the faucet may be hard or soft, may have a distinctive taste or none at all, may be clear or slightly cloudy, and may be cool or warm. These properties and many others distinguish one kind of water from another. To speak of the quality of water is to describe its individuality. Today, much is heard about water quality. In a practical sense this term means those traits that are distinctive to a body or supply of water in relation to some use-for example, drinking, irrigation of croplands, manufacturing, food processing, or recreation.

Water quality is relative. Rapid-forming deposits in hot-water tanks and in tea kettles plague people who must use unsoftened water. But if the water is too soft, the coffee doesn't taste right. On vacation, you may have trouble adjusting to a new water supply if its quality is different from that back home. Even though a domestic water supply is satisfactory in all respects for drinking purposes, distilled water is preferred for use in automobile storage batteries. Why is this so? Because living cells accept, in fact require, certain minerals in the water, but for battery cells the opposite is true. "Quality" then must be associated with the intended use of the water and has many meanings. No one definition means the same thing to all people.
Water quality is influenced by natural factors and by the activities of man. Before considering these effects upon water, you should know about the structure and unusual properties of water as a chemical compound.

\section{WATER'S STRUCTURE AND UNUSUAL PROPERTIES}

For many years, water was thought of as a simple chemical compound whose formula could be represented as $\mathrm{H}_{2} \mathrm{O}$, or two parts hydrogen and one part oxygen. It was known that two atoms of hydrogen combined with one atom of oxygen to form a molecule of water, or $\mathrm{H}_{2} \mathrm{O}$. A molecule, by explanation, is the smallest unit of matter that can exist by itself and retain its chemical identity. Consider sugar and table salt, two chemical compounds used every day in the kitchen. Both compounds consist of large numbers of molecules. Atoms of carbon, hydrogen, and oxygen combine in definite proportions to form a molecule of sugar. Similarly, atoms of sodium and chlorine unite to form a molecule of table salt. Though not visible to the eye, a molecule of sugar has the same structure and properties as the sugar added to a cup of coffee. Likewise, the molecule of table salt differs in no way from the salt used to season one's food. 
In 1934 the concept of the water molecule had to be changed because another kind of hydrogen was discovered in water's structure. This new substance, called deuterium, is twice the weight of the normal hydrogen atom. The symbol " $\mathrm{D}$ " is assigned to deuterium, which also combines with oxygen in the ratio of two to one to form $\mathrm{D}_{2} \mathrm{O}$. A common name for $\mathrm{D}_{2} \mathrm{O}$ is "heavy water." Later, still another kind of hydrogen, called tritium, was discovered. Tritium ("T") is three times the weight of ordinary hydrogen and combines with oxygen to form $\mathrm{T}_{2} \mathrm{O}$. Pure water contains very small quantities of $\mathrm{D}_{2} \mathrm{O}$ and $\mathrm{T}_{2} \mathrm{O}$ in proportion to $\mathrm{H}_{2} \mathrm{O}$.

Deuterium and tritium are isotopes of hydrogen, that is, they are varieties of the same element, similar in chemical behavior, but differing in weight. Hydrogen, deuterium, and tritium are like brothers who are triplets. The three brothers have about the same behavior patterns and personality traits, but one boy weighs only 100 pounds, the second boy weighs 200 pounds, and their brother, the heaviest of all, weighs 300 pounds.

The structure of water is further complicated by the fact that oxygen, like hydrogen, has three isotopes. The combining of the hydrogen and oxygen isotopes in the ratio of two to one results in a mixture of 33 different substances, some made up of distinct molecules and some of which exist only as electrically charged parts of molecules, called ions. More will be said about ions in the discussion of water as a solvent.

The common formula for water, $\mathrm{H}_{2} \mathrm{O}$, need not be rejected, because pure water is virtually what this formula says it is. It is important to remember, however, that water is not a single, simple compound. Actually, less is known about water than about many other liquids.

Water has many unusual properties. It alone occurs naturally on earth in three distinct forms at the same time - as solid, liquid, and gas; on a winter day, water appears as ice in a partly frozen creek, as a liquid in open stretches of the stream, and as clouds in the sky. Water expands when it freezes, whereas most substances contract; anyone who has had to replace a burst water pipe or automobile radiator knows about water expansion from experience. A solid steel ball is heavier than an equal volume of molten steel, and most other substances are heavier in solid than in liquid form, but a block of ice is lighter than an equal volume of water.

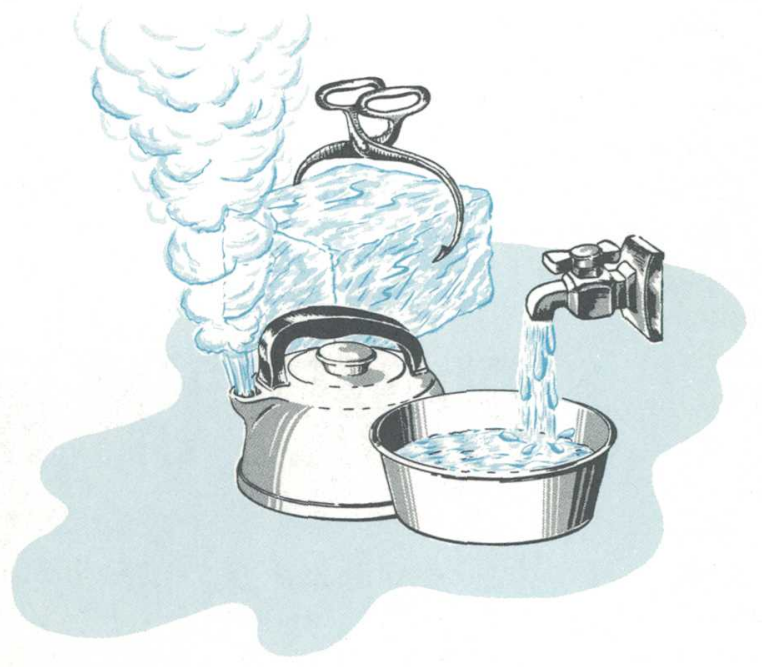

Water takes its time to come to a boil-a vexing fact to those who want their morning coffee in a hurry. That the pot, watched or unwatched, boils slowly is another way of saying that water has a very high heat capacity and can absorb a great amount of heat without much rise in temperature. Water's heat capacity is so high that it is a standard against which the heat capacities of other substances are measured. Because of water's heat characteristics, the oceans serve as controls in helping to prevent climatic extremes.

Another unusual property of water is its surface tension which is the highest of all common liquids with the exception of mercury. Surface tension is the ability of a substance to stick to itself or to cohere. It causes water dripping from a faucet to stick together to form spheres or water drops. Water can stick or adhere to solid substances such as rocks and soil as well as cohere to itself. These cohesive and adhesive forces of water are important in understanding the movement of water in soil. A drop of water tends to spread out in a thin film over particles of soil and to cling to the surface of these particles. Through capillary action, which depends upon the molecular attraction of a solid for a liquid, water may be pulled downward into dry soil below the wetter portion. When the soil particles are coarse, that is, consist of sand or small pebbles, the water moves more rapidly under the influence of gravity through the larger openings between the particles. 
Most remarkable of all water's uncommon properties is its ability to dissolve so many substances. Of all liquids known, it is nearest to a universal solvent. Pour some table salt (sodium chloride) into a glass of tap water. The salt crystals dissolve and are distributed evenly throughout the water as invisible ions which, as noted in the discussion of water's structure, are electrically charged parts of a molecule. In this example, tap water is the solvent, the table salt is the dissolved substance (called a solute) and the resulting homogeneous mixture is called a solution. The water in oceans, rivers, lakes, springs, and wells is really a solution of many substances in ionic form. Most of the known chemical elements have been identified in waters of the earth. Some elements (sodium and chlorine in sea water are examples) are dissolved in significant quantities, but many elements are found in trace amounts only. Water's function as a solvent has added importance because water is generally not changed chemically by the substances it dissolves and therefore can be salvaged for reuse. Water can be called an inert solvent.

\section{HOW NATURE AFFECTS WATER QUALITY}

Since the world began, natural processes have influenced the chemical, physical, and biological characteristics of water. Even rainwater contains small amounts of dissolved minerals, called salts, which have been transported by winds blowing across the ocean or the land surface. In addition to salts, rainwater contains particulate matter, such as dust particles, and dissolved gases, such as carbon dioxide and sulfur dioxide. Although rainwater has few minerals, the amount of salts brought down by precipitation over a given area and time may total many tons. Some idea of the contribution to rivers and creeks is obtained from a U.S. Geological Survey study of a 33,000 square-mile area in eastern North Carolina and southeastern Virginia. During August 1962, rainwater contributed, in addition to other minerals, 10,200 tons of calcium to streams in this region. The salts contributed by rainwater were added to salts from local origin.

Natural quality of water varies from place to place, with the season of the year, with the climate, and with the kinds of rocks and soil through which the water moves. After reaching the earth, water dissolves minerals from the earth's crust, percolates through organic materials such as roots and leaves, and reacts with living things such as microscopic organisms like plankton or algae. Natural water quality is altered by wind- or stream-transported sediments. It is modified by water temperature, by soil bacteria, and by evaporation. These and other environmental factors determine the quality of water found in nature.

Common table salt from saline springs and other sources affect water quality. For example, it has been estimated that 25,000 tons of salt per day are discharged from springs into otherwise satisfactory waters of the Arkansas and Red River basins. Some springs are reported to yield as much as 500 tons or more of common salt each day.

Living organisms exercise natural quality controls both on fresh water and sea water. Studies by the Geological Survey of Birch Creek in California suggest, for example, that algae and moss help to separate the mineral calcite from the creek water. These plants vary in abundance, and their effect on water quality in general differs from the source of a stream to its mouth, and from one stream to another.

A lake undergoes evolutionary changes from the time of its creation. These changes take place at different rates for different lakes. The water of a young lake initially contains small amounts of dissolved minerals essential for plant growth. It usually is sparkling clear, contains abundant oxygen, and supports only sparse growths of rooted plants and other flora. After many years, dissolved minerals, including such plant nutrients as nitrates and phosphates, increase. The water is turbid or cloudy and commonly contains abundant plant growths which on decay give off an unpleasant odor or impart to the water a swampy taste. Oxygen levels decline and decomposition products accumulate. Organic matter at the lake bottom, where free oxygen is absent, is attacked by bacteria which release hydrogen sulfide, a foul-smelling gas suggestive of rotten eggs.

In some coastal areas, certain algae, the simplest form of plant life, secrete poisons which destroy marine life. The algae contain pigment cells that change from yellow to red. It is these microscopic algae that sometimes accumulate in uncounted billions and cause that bane of fishermen, the dreaded "red tide." 
He who travels soon becomes aware of natural variations in water quality. Many spring waters are world renowned because of their distinctive mineral properties. Some streams are clear at their source but become muddy a few miles downstream. Wells a short distance apart and dug to the same depth may yield water dissimilar in quality. Lake water may be fresh or salty, may have a characteristic odor or taste, and may even have an unusual feel as, for example, the alkaline water of Soap Lake in central Washington when you dip your hand in it. In one area in the Midwest, wells provide a soft water that tastes like a weak solution of baking soda and, say local residents, "sounds and acts like Seltzer water."

Some streams and lakes take their names from their appearance, as Milk River, Mont., and Muddy Creek, Wyo., or from a characteristic property, as Stinking Water Creek, Nebr., Saline River, Kans., and Sweetwater Lake, N. Dak. Other names are associated with the kinds of rocks and soil through which the waters flow, as Limestone Creek, Ala., Black Earth Creek, Wis., Red Clay Creek, Del., and Granite Creek, Calif.

\section{THE WATER CYCLE}

Water has no fixed address; it circulates or moves from the land to the oceans, to the atmosphere, and back to land again. This continual exchange between the earth and the atmosphere is called the water or hydrologic cycle. The cycle has certain phases: Under the warming influence of the sun, water evaporates from lakes and reservoirs, from the leaves of trees and plants, and from wet ground. This water vapor rises and is carried in the air as a gas; when it collides with a colder mass of air, it condenses (changes from a gas to a liquid) and falls as rain. The rain runs off into streams, which in turn transport water to the ocean. Evaporation from both the land and the ocean causes water to return to the atmosphere as vapor.

Throughout this cycle, some changes take place in quality of the water (see fig. 1). On evaporation, for example, water escapes to the atmosphere as salt-free vapor, and the salts or minerals remain behind. Where rainfall is insufficient to flush these salts back into solution, they accumulate in the soil or on exposed stream beds, river banks, and lake shores. Salt residues are com- mon sights in many parts of the western United States, but are seldom seen in humid areas. Nor are there any salt residues along the western slope of the Olympic Peninsula in Washington, where the average rainfall is more than 140 inches per year-the heaviest of any place in the continental United States.

\section{RIVERS CARRY SALTS AND SEDIMENTS}

Rivers have remarkable erosive power; that is, flowing water can break down rocks, dissolve the soluble minerals, pick up sediments, react with soil materials and plant and animal matter, and carry these products in solution or suspension for long distances. Water's ability to dissolve many substances is increased by the carbon dioxide absorbed from the air. Rivers may transport very large amounts of dissolved minerals or salts. The Niagara River, for example, as it sweeps over Niagara Falls carries on the average more than 230 million pounds of dissolved minerals each day. This salt load, corresponding to a rate of about 80 tons a minute, would fill a railroad hopper car of average capacity every 45 seconds.

Rocks vary in their resistance to solution. Some rocks, granite, and lava, for instance, are not readily dissolved by water, but other rocks such as limestone, gypsum, and marble are more soluble. The quantity and kinds of dissolved minerals carried by water depend chiefly on the types of rocks and soils with which the water comes in contact and the length of time of this contact.

Rivers carry sediments as well as salts. The presence of salts in water is accurately determined only by chemical analysis, although sometimes the sense of taste tells one that a water is salty or acid. Sediment in streams, on the other hand, is usually apparent to all because it gives the water a muddy appearance. Even if a river appears to be sediment-free, a glass container of water scooped from the stream may show sediment particles. Rivers carry sediment particles of varying size, shape, and kind. These particles are in suspension or else move along the riverbed. Sediment is classified according to particle or grain size. Fine-grained sediments are described as clay, silt, and sand, and coarse sediment is called gravel. During rainstorms or spring thaws, sediment is washed into stream channels from areas where soil is exposed and where erodible earth materials such as alluvium, shale, and siltstone are accessible to flowing water. 


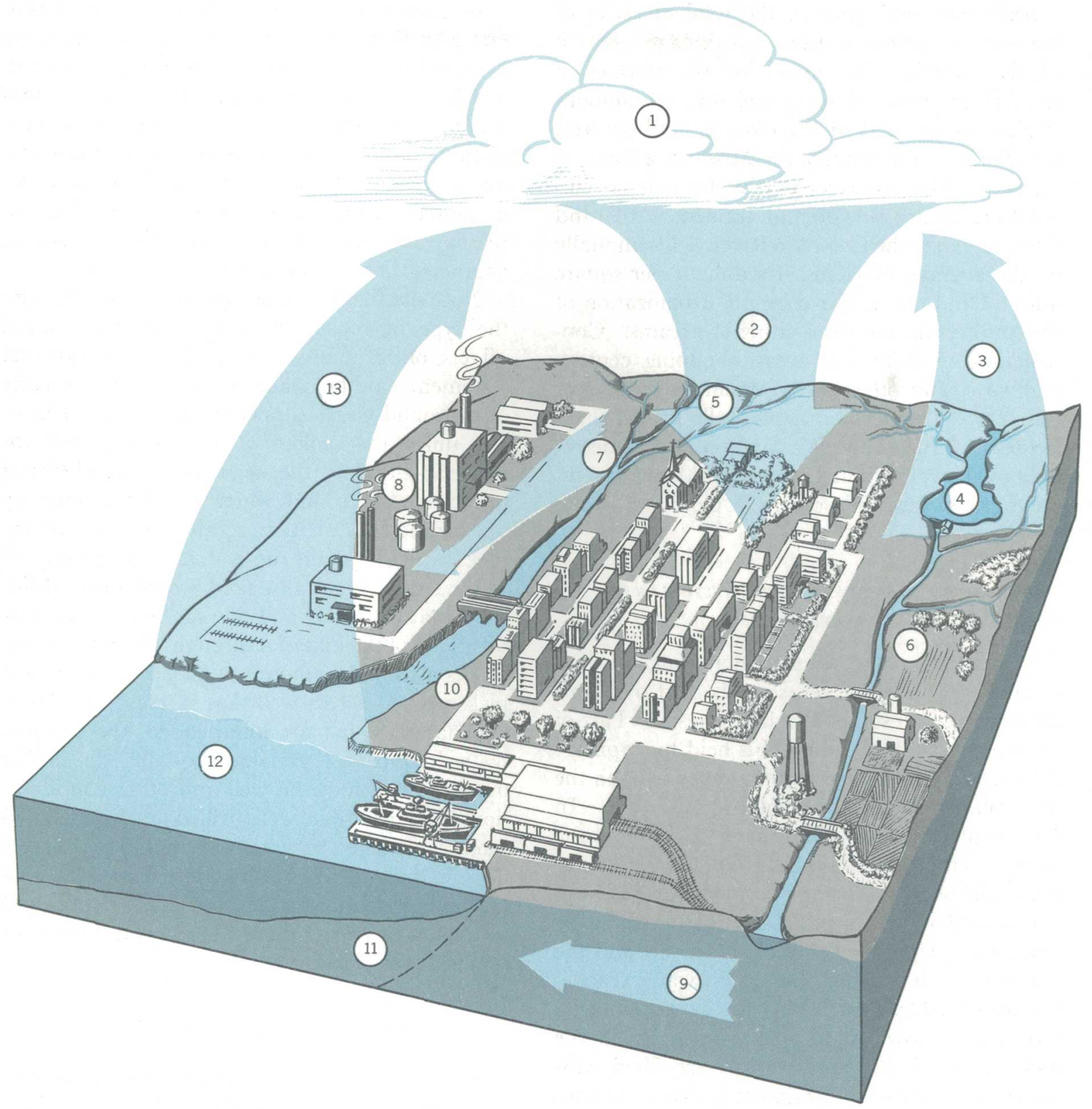

(1) Water vapor mixes with gas and dust in clouds

(2) Vapor condenses around small particles to form rain or snow

(3) Evaporation increases concentration of minerals in water left on the earth

(4) Changes in water quality of lakes due to physical, chemical, and biological processes

(5) Quality of surface water is modified by contact with soil and air

(6) Irrigation increases concentration of salts in water

(7) Surface-water quality further modified by chemical reaction among salts, sediments, and biological materials in the water
(8) Cities and factories add chemical and organic pollutants to water

(9) Ground water modified chemically and physically by minerals and gases dissolved from the rocks

(10) Salt water from ocean mixes with fresh water from river (surface water)

(11) Mixing along salt-fresh water interface (ground water)

(12) Water quality in ocean altered by physical, chemical, and biological processes

(13) Duśt and spray are picked up by air movement from the land and/or water surfaces and introduced into the atmosphere

FIGURE 1.-How water quality is changed as water moves through the water cycle. 
Sediment yield, that is, the total quantity of sediment contributed from a drainage area, is highly variable. It depends on the amount of rainfall, the kinds of rocks and soil, the amount of plant cover, and such factors as land use and streamflow. The yield of the Mississippi River at St. Louis, Mo., averages yearly 260 tons of sediment per square mile of land drained. At Grand Canyon, Ariz., the Colorado River yields annually on the average 670 tons of sediment per square mile. Land use, as for example urbanization of the countryside, increases silting of streams. Construction of residential areas, shopping centers, highways, and other service facilities exposes or reshapes soil material. Little Falls Branch near Bethesda, Md., in the Washington, D.C., metropolitan area, contributed about 2,300 tons of sediment per square mile during a period of urban development.

\section{GROUND WATER REACTS WITH EARTH} MATERIALS

When rain falls, some water runs off into streams, some evaporates, some is used by plants for growth, and some sinks into the soil. Part of the water that enters the soil is held by capillary action, which, as noted earlier, depends upon the molecular attraction of a solid for a liquid. In this capillary action, soil and rocks compose the solid, and the falling rain is the liquid. The water thus held takes the place of water that has been evaporated or used by plants during the preceding dry spell. After the needs of the plants and the soil have been satisfied, the excess water reaches the water table, that is, the top of the zone of saturation below which all the openings in the rock-pores, holes, and cracks-are filled with water; this zone of saturation may extend to considerable depth. When rain reaches the water table, it becomes "ground water." Ground water flows, very slowly, but it flows as truly as does the water in a river, and for that reason it may be tapped by wells, or emerge as springs, or seep into a stream miles from its point of entry into the ground. In most streams the water that flows during dry spells is largely ground water. This base runoff, as it is called, is ground water that seeps out of the soil into streambeds when the water level of the stream drops below the level of the water table. Flow of streams is measured in feet per second, but movement of ground water is usually measured in feet per year.
Because ground water is in much longer contact with rocks and soils, it usually contains more dissolved minerals than does the water of streams or lakes. During dry periods, the mineral properties of river water generally approximate those of the ground-water inflow, but in the rainy season or at times of heavy snowmelt, river water is diluted and much less mineralized. For this reason, river water is more variable in chemical character than ground water.

Not only the length of time of contact but also the type of rocks and soils determine natural effects on ground-water quality. No general statement can be made as to expected quality of a ground-water supply from specific rocks or soils unless the geology of the region is well understood-that is, the occurrence and chemical properties of ground water are determined by the character, distribution, and structure of the rocks which contain the water. The quality of water from gravel and sand would likely differ from that from clay and fine silt because the permeability of the material through which the water moves affects the amount of dissolved minerals it picks up. Where a well taps several water-bearing materials that are interbedded, the pumped water frequently is variable in quality, depending upon the depth of the well and other considerations. For example, wells drilled into interbedded sand, shale, clay, siltstone, sandstone, and lignite deposits in parts of northwestern North Dakota normally yield hard water at shallow depths and soft water at greater depths (hard water does not readily form a lather with soap).

\section{MAN AND HIS WASTES}

The discussion so far has considered some natural causes of water quality. Added to these causes are those actions of man which affect the quality of the Nation's surface and ground waters (fig. 2). Natural processes contributing dissolved and suspended material to water are virtually beyond man's control, but the releases of industrial, agricultural, and municipal wastes to streams and underground water supplies are activities of man and, to varying degrees, controllable. The word "pollution" is commonly used when these activities of man are of such nature as to degrade the natural quality of the water. Pollution, however, like the term "quality" has many meanings. To some people, pollution means acid mine wastes 


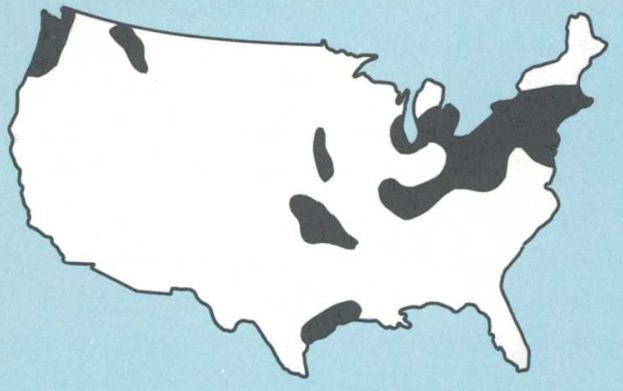

INDUSTRIAL WASTES

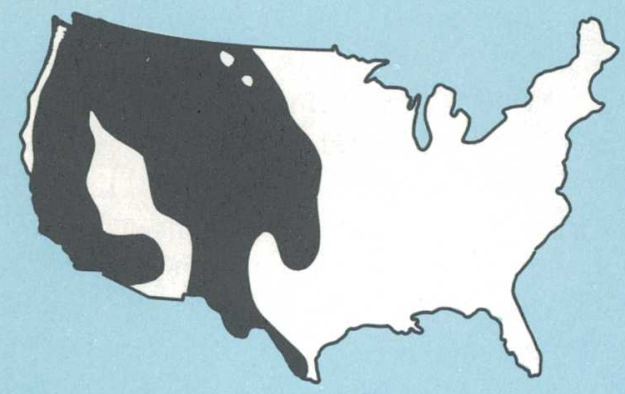

IRRIGATION RETURN FLOWS

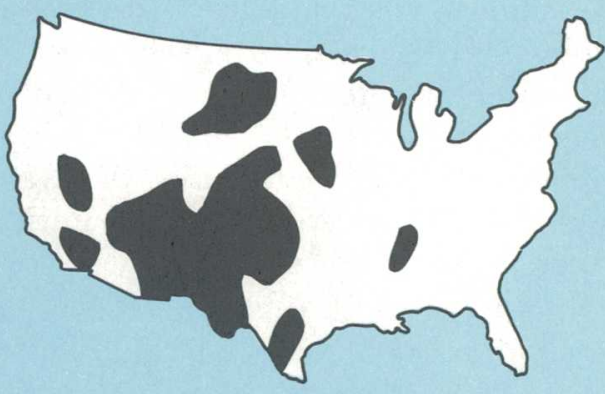

SILT IN RESERVOIRS

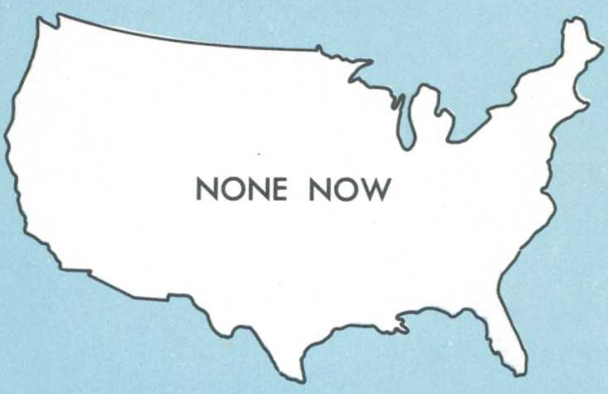

RADIOACTIVE DISSOLVED MATERIALS

FIGURE 2.-Some water-quality problems result from man's actions.

flowing into a stream; to others, the introduction of pesticides and agricultural chemicals, or the discharge of untreated sewage, or sediment from urban development. To the angler, it may be water temperature too high for sport fish to survive. A Colorado court decision in 1934 defined pollution thus:

* * For the purpose of this case, the word "pollution" means an impairment, with attendant injury, to the use of water that plaintiffs are entitled to make. Unless the introduction of extraneous matter so unfavorably affects such use, the condition created is short of pollution. In reality, the thing forbidden is injury. The quantity introduced is immaterial.

Perhaps the simplest definition of pollution would be "any impairment in water quality that makes the water unsuitable for beneficial use."

All this is not to say that water was pure before man came along. Geologists maintain that the physical environment has changed many times, but there is no evidence that water was pure until the appearance of man. In the beginning, the atmosphere was saturated with gases-hydrocarbons, carbon dioxide, and ammonia. By pres- ent-day standards, this primitive atmosphere was extremely polluted. For a brief period, geologically speaking, after plant life had developed and trees and shrubs had begun to release oxygen to the air, both the air and the water environments were relatively pure. Even after the appearance of man, there was little change in the quality of water for a long time.

It was the rise of civilization and the grouping of people in pueblos and cities that brought problems of water pollution. Man's wastes were dumped untreated into any convenient watercourse. Little thought was given to the effects of polluted water on downstream users or on aquatic life. Not until the middle of the 19th century was the role of polluted drinking water in the spread of such water-borne diseases as cholera and typhoid fever demonstrated, and as late as the beginning of the present century in some of the larger communities of North America, typhoid fever still exacted an annual death toll of more than 115 per 100,000 population. Today this disease has been almost eliminated, primarily 
through proper methods of water supply, filtration, and disinfection and by safe procedures of waste-water disposal. Although polluted drinking water in community water supplies is no longer a problem in the United States, it is still today a great obstacle to raising the living standards of many underdeveloped countries of the world.

Industry requires water for making its products, for cooling or heat exchange, and for washing, grading, or moving of materials. Processed foods, beverages, most synthetics, and countless other commodities require water, and for many of these uses the water must be of high quality. Water must be available moreover to flush away wastes, and there are almost as many different kinds of industrial wastes as there are industries. Mining, oil fields; and metal-plating works produce acids, alkalies, and salts. From paper mills come waste fibers and chemicals. Food-and meat-packing plants discharge vegetable and animal wastes.

Without water most industries could not function, and without industrial development presentday standards of living in the United States would not have been achieved. Many of the large industries are concentrated along a few great rivers. At first the flows of these rivers diluted the wastes, the organic matter was oxidized, and the inorganic substances were dissolved or carried away; however, streams have a limited ability to purify organic wastes. If this natural or selfpurifying ability of running water to assimilate and to stabilize wastes is overtaxed, the river becomes turbid, sunlight cannot penetrate into deep water, and green plants die because they need sunlight for photosynthesis to remove carbon dioxide from the water and release oxygen to it. When this happens, action must be taken to restore the water's natural forces of purification.

\section{WASTES RESULT FROM USE}

Water pollution existed, of course, long before the United States became an industrial power; it is as old as civilization. What has brought water pollution into public focus in recent years is the enormous increase in use of water. Economic and population growth not only multiplies demand for water-it simultaneously swells the volume of waste materials reach- ing watercourses. Consider water demand: During April 1964 the United States was withdrawing water for use at a rate equivalent to 118 trillion $(118,000,000,000,000)$ gallons a year. This tremendous amount is about one-tenth the volume of water in Lake Huron; yet, despite this large rate of use, national water needs are increasing at a rate of about 25,000 gallons per minute. Fortunately, much of the withdrawn water is not consumed but is returned to a downstream or underground source after use.

Degradation of water quality is, nevertheless, inherent in use, and water in the Nation's river systems is withdrawn for use many times and for many purposes, including transport of wastes. The transport of wastes from the home, factory, or farm to the sea is a beneficial use of water, but at times man offends nature. When such wastedisposal practice is abused, problems arise and controls become necessary for the benefit of the community as a whole. Realistically, the wastewater problem consists of learning how to handle wastes, not how to stop waste disposal. Obviously, streams must not be overloaded with wastes. Although treatment of waste is necessary, the degree of treatment required depends in part on the quantities of water available for dilution in the receiving waters. The most economical solution to the pollution-control problem may lie in partial treatment of waste in combination with increase of low flows by means of reservoir releases. Where water is scarce, wastes may require complete treatment. Pondage of some wastes for release during periods of high flows is often practical.

Industry in general is aware of its responsibility to downstream users of water. Many industries are devoting time, money, and research to solving problems of industrial-waste disposal. The pulp and paper industry, in particular, has been most interested in promoting research at various universities. Similar efforts at conservation and waste control are being made by the steel, coal, and petroleum industries.

\section{SOME WASTE-WATER PROBLEMS}

Newspaper and magazines currently contain many items about water pollution and problems caused from wastes discharged into waterways, primarily by industry. It is true that techno- 
logical advances since World War II have introduced many new types of wastes into the earth's environment, and no end is in sight. Only a few of these wastes can be considered in a primer on water quality.

Stream pollution is sometimes accidental. On April 17, 1964, to cite one example, tank cars of a freight train derailed at Orleans Crossroads, W. Va., spilled thousands of gallons of liquid products including an organic ammonia compound, refined and waste oils, and soybean oil into Brooks Run, a tributary to the Potomac River. Because Washington, D.C., 128 miles downstream from the area of spillage, draws on Potomac River water as its source of public supply, extra precautions were taken by water-department officials to assure the safety of the drinking water.

Pests and insects compete with man for food. Pesticides, insecticides, weed killers, and similar products are widely used on field and garden crops because of their effectiveness in destroying objectionable insects and nuisance plants. Since the introduction of the pesticide DDT in 1944, about 500 kinds of synthetic organic pesticides such as chlorinated hydrocarbons have been placed on the market, and these compounds are incorporated in thousands of different formulas. Many of these organic compounds are complex in chemical structure and have highly technical names. For example, endrin, one of the more publicized toxic pesticides, is known to chemists as of $1,2,3,4,10,10$-hexachloro-6, 7-epoxy-1, 4, $4 a, 5,6,7,8,8$ a-octahydro-1, 4-endo, endo-5, 8dimethanonaphthalene. According to the President's Science Advisory Committee Panel on the Use of Pesticides, an estimated 350 million pounds of insecticides were used in the United States during 1962. Annually, about 90 million acres of farmlands, forests, and insect-breeding areas, including wetlands, are sprayed with insecticides. Substantial amounts are used also for gardens and around homes.

Pesticides enter streams and wells from treated areas through runoff of rain or through percolation in soil. Transported from one place to another not only by water runoff and percolation, but also by air currents and living organisms, pesticides may travel great distances and persist in water or soil for long periods of time. Residues of these complex organic chemicals have been detected in most major rivers, in ground water, in fish from fresh waters, in migratory birds, in wild mammals, and in shellfish. Even though pesticide residues remain in trace amounts, their biological significance is important, although not all aquatic biologists agree on the exact relationship between pesticides and fish kills.

Certain organic pesticides, such as the chlorinated hydrocarbons, are very stable; that is, they do not break down into their component parts in water and disappear, nor are they completely removed by sewage-treatment or water-purification plants. The pesticide problem poses many questions: How long do pesticides persist in a watercourse? What are the effects on aquatic life, both animal and vegetable, which makes up the food chain of fresh-water and marine fish? Many people believe that long-term effects on man may be extremely serious, but no one is quite sure. Scientists in government, universities, and industry are seeking answers to these unknowns, but much remains to be learned about the biological significance of pesticides and their persistence in natural waters.

Synthetic detergents have contributed to wastewater problems. These surface-active agents, as they are called, were developed to overcome the disadvantages of ordinary soap in hard water. Soap in its cleansing action forms insoluble compounds, or scum, and often causes many washed fabrics to appear dingy. Synthetic detergents, on the other hand, maintain their efficiency in hard water without formation of scum, and 2.4 million tons are produced annually to satisfy the enormous demand of home and of industry. But though these detergents do the cleansing job well, the specific surface-active agent most widely used in synthetic detergents - a chemical called alkyl benzene sulfonate or ABS-causes foaming in streams and in some localities a head of suds on water drawn from the tap. This foaming results from the fact that detergent wastes reaching sewage-treatment plants do not break down biologically; that is, ABS and compounds of similar structure are not decomposed by bacteria in the water. ABS, then, can travel long distances in streams and through the ground without losing its identity. In addition to foaming and frothing, detergent wastes retained in filtered municipal water supplies have caused taste and odor 
problems. The off-taste has been described as oily, fishy, or perfumelike.

Industry believes it has found the answer to foaming and related problems in chemicals which will replace ABS. One new compound, or group of compounds, is called linear alkylate sulfonate, abbreviated LAS. The structure of LAS is such that detergent wastes containing this material decompose readily by bacterial action. This new compound together with improved waste-treatment processes may prove to be a constructive step forward in disposal of detergent wastes.

Another waste-water problem is the discharge of acid from active or abandoned mines, particularly coal mines. Where coal is mined, an associated mineral called pyrite containing iron and sulfur is exposed to water and air. As a result of this exposure or weathering, the pyrite breaks down to form sulfuric acid and acid-producing compounds of iron. Through pumping or by natural drainage, the acid wastes flow into nearby streams. Unable to neutralize completely these acid wastes, many streams become unfit for use by man, and no longer can support fish life. Without extensive treatment the polluted water will not meet requirements of most domestic and industrial users. Other difficulties result from damage to concrete and metal in bridge piers, dams, turbines, and culverts by the corrosive acid water.

The Monongahela River, draining parts of West Virginia and Pennsylvania, is an example of an acid stream. On the average, this stream empties the equivalent of 200,000 tons of sulfuric acid each year into the Ohio River. This amount of acid is about twice that used annually in the manufacture of industrial explosives in the United States. Assimilation of acid by the Ohio River begins immediately. By the time the Ohio has passed the mouth of the Muskingum River at Marietta, Ohio, 170 miles downstream from the Monongahela River, the acid load has been neutralized completely.

The control of acid wastes from min $2 \mathrm{~s}$ has no easy solution. The problem is receiving much study and has already been the subject of extensive investigations by government, university centers, and industry. A joint Federal-State study begun in 1964 at a demonstration site in the Roaring Creek-Grassy Run area near Elkins, W. Va., may lead to a better understanding of the factors con- tributing to the problem. Several techniques for controlling acid wastes are known: Closing or sealing of abandoned mines, diversion of surface and ground water from mine workings, prompt removal of mine drainage from acid-forming materials, and regulating release of acid wastes to receiving streams are some.

Like other industries, the nuclear-energy industry has waste-disposal problems and hazards. However, radioactive wastes are different from other industrial wastes in important ways: Radioactivity is not detectable by human senses, and radioactive materials, which are biologically significant in extremely low concentrations, lose their toxicity only by natural decay. Different radioactive elements are taken up by different body organs. Strontium 90, for example, deposits in the skeleton and exposes bone and bone marrow to radiation and for all practical purposes is not eliminated. Moreover, strontium 90 has a half-life of about 28 years. A half-life is the time necessary for half a given quantity of material to decompose or lose its activity.

Water quality can be affected only by those radioactive wastes that are discharged to the environment. Wastes containing low levels of radioactivity commonly undergo treatment and then are released into streams or seepage pits. The most highly radioactive wastes are not released, however, but are stored in underground steel tanks. Storage in underground tanks, too, can be hazardous. The hydrology and geology of storage sites must be thoroughly studied to avoid contamination of the water by radioactive wastes, should leakage occur.

Federal agencies and industry are working together on studies of the technical feasibility of storing radioactive wastes in natural geologic formations where they will be safely contained indefinitely. For this purpose, more information must be obtained about the movement of liquids through porous rock and about the dispersion of radioactive isotopes in water and their retention by earth materials.

The radioactivity from delayed fallout is a waste product from weapons testing of nuclear explosives. Although large quantities of radioactive debris have been spread over the land and water surfaces of the world and although levels of radioactivity in water have been increased over 


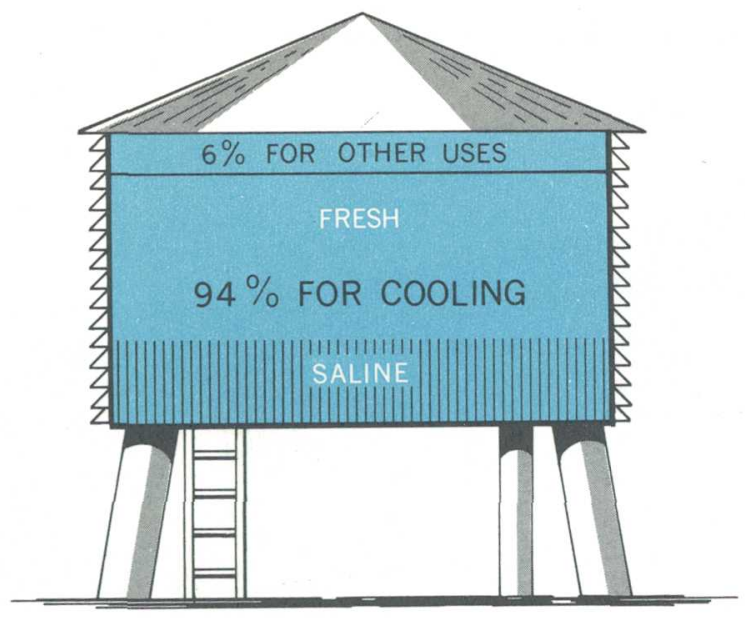

FIGURE 3.-Use of industrial water.

their natural or background level, water quality has not been seriously affected because fallout particles tend to become attached to the soil or to plants and are not readily transported to streams and into ground water.

It may be hard to believe, but abnormal heat is considered a pollutant of water. Few people realize how important temperature of water may be. For one thing, it can determine the species of fish that will live and reproduce in a given body of water. Temperature also governs the amount of dissolved oxygen in the water, which is essential to fish and plant life. Steam-electric powerplants, steel mills, petroleum refineries, and other industrial plants withdraw huge amounts of water daily from rivers and lakes for cooling purposes (fig. 3). These withdrawals, slightly reduced in volume and warmer by as much as $30^{\circ} \mathrm{F}$, are returned to the watercourse after use. The heat thus transferred reduces the ability of a stream to hold dissolved oxygen, because oxygen is more soluble in colder water. Increased temperature has a serious indirect effect. Oxygen combines more rapidly with organic wastes as the water temperature increases. Thus the dissolved oxygen may be consumed more rapidly than it can be replaced as the water flows downstream. The minimum oxygen content may be zero.

Ideally, heated waters should be cooled before discharge so the receiving stream can maintain required oxygen levels. This cooling can be done through the use of still ponds, spray ponds, or cooling towers.

\section{GHARACTERISTICS OF WATER}

Because of the remarkable solvent property of water, the world's oceans, rivers, lakes, springs, and wells are, in effect, solutions of many substances in ionic form, that is, of tiny, electrically charged parts of a molecule. Gypsum (calcium sulfate) dissolved in water, for example, yields calcium ions and sulfate ions. Calcium sulfate is one of many kinds of salts that commonly occur naturally in water, others being combinations of sodium, potassium, calcium, and magnesium, called positive ions or cations, plus carbonate, bicarbonate, chloride, sulfate, and nitrate, which are negative ions or anions.

The proportions or concentrations of salts in water is a determining factor in evaluating its quality. The concentration of salts in fresh water is, on the average, so small that it is expressed in parts per million ( $\mathrm{ppm})$. For example, a concentration of $100 \mathrm{ppm}$ means that a million pounds of water contains 100 pounds of salt. If you added a pound of ordinary table salt to a million pounds of water, you would have a salt concentration of $1 \mathrm{ppm}$. The dissolved material in rivers is usually less than $500 \mathrm{ppm}$, though some rivers may contain 2,000 or more ppm. Distilled water for automobile batteries is saltfree, or $0 \mathrm{ppm}$. Some examples of average concentrations of dissolved salts in water are shown in the following table:

\begin{tabular}{|c|c|}
\hline Source of water & Salt concentration \\
\hline Distilled & 0 \\
\hline Rain & 10 \\
\hline Lake Tahoe & 70 \\
\hline Suwannee River & 150 \\
\hline Lake Michigan & 170 \\
\hline Missouri River_-_ & 360 \\
\hline Pecos River & 2,600 \\
\hline Ocean & 35,000 \\
\hline Brine well & 125,000 \\
\hline Dead Sea & 250,000 \\
\hline
\end{tabular}

The concentration of dissolved materials in natural water is not fixed or unalterable. A range in concentration is the rule rather than the exception, although the chemical content of ground water tends to remain more stable than that of surface water. The salt concentration in Great Salt Lake, Utah, the largest surface-water area in the Western Hemisphere without drainage to the ocean, has fluctuated with time-it has ranged from about $150,000 \mathrm{ppm}$ ( 15 percent) during the high-lake stages of the 1870's to about 


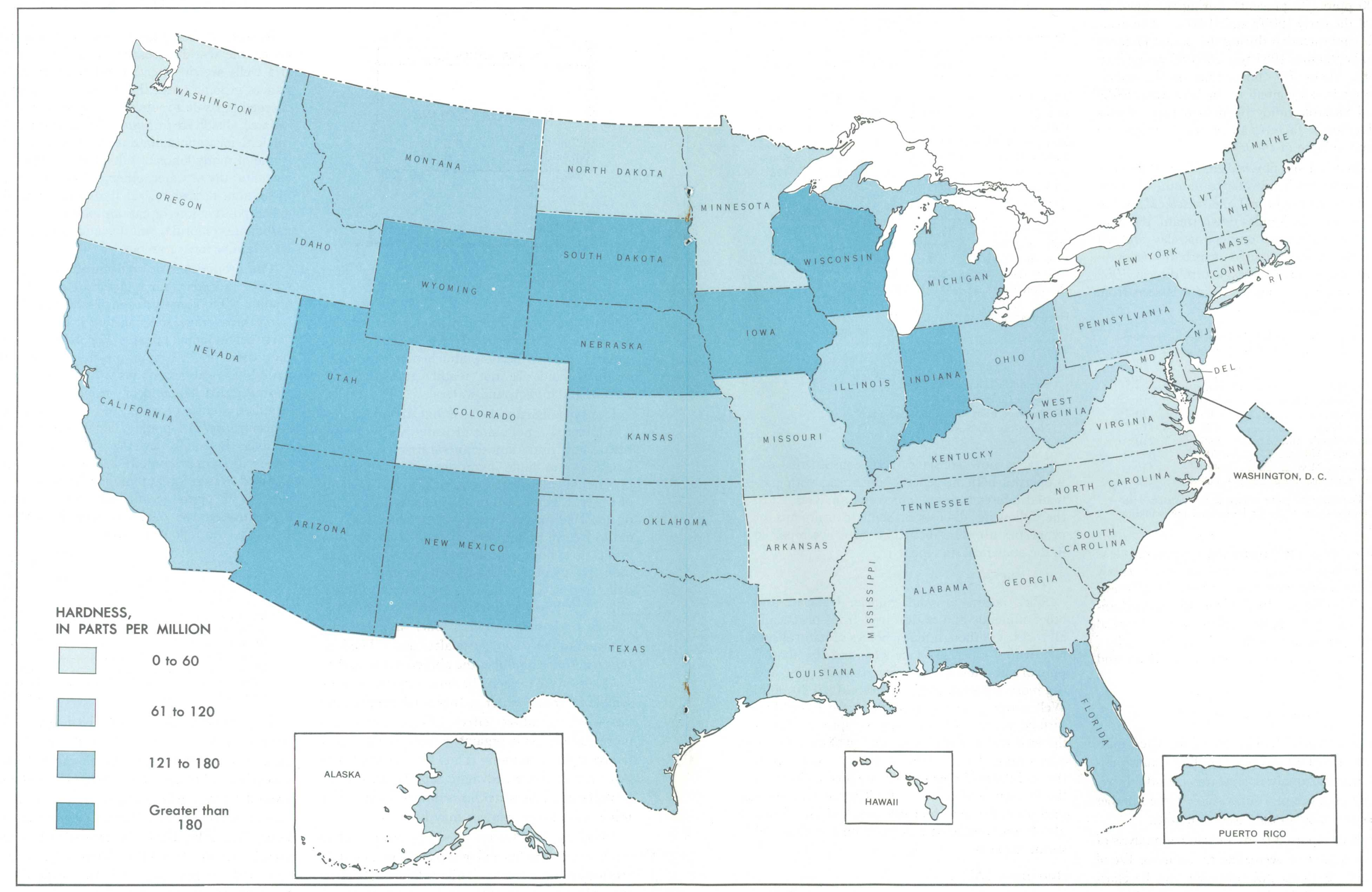

FIGURE 4.-Weighted average hardness, by States and Puerto Rico of water delivered from 1,596 public supplies, 1962. 
$280,000 \mathrm{ppm}$ (28 percent) during the low-lake stages of the early 1900's and 1960's. The average salt concentration during the period October 1959 to September 1961 was 266,000 ppm (26.6 percent), about $71 / 2$ times that of sea water. This range in salt content of the lake water is the result of variable inflow from tributary streams and of climatic factors, all of which affect the stage and volume of the lake.

The chemical and physical character of a river's water varies from headwater to mouth. For example, from its origin in Lake Itasca, Minn., to New Orleans, 2,375 miles downstream, the Mississippi River picks up or deposits clay and silt with much resulting change in turbidity (cloudiness) of the water. Average turbidity in 1962 in seven reaches of the Mississippi is seen from the following data:

Average turbidity of Mississippi River water from Minneapolis to New Orleans, 1962

\begin{tabular}{|c|c|c|}
\hline Location & $\begin{array}{c}\text { River miles } \\
\text { belowo } \\
\text { Minneapolis }\end{array}$ & $\underset{(p p m)^{1}}{\text { Turbidity }}$ \\
\hline Minneapolis, Minn_-_- & 0 & 10 \\
\hline Davenport, Iowa & 380 & 70 \\
\hline Alton, Ill & 672 & 110 \\
\hline East St. Louis, Ill, & 698 & 210 \\
\hline St. Louis, Mo & 701 & 593 \\
\hline Vicksburg, Miss & $-1,490$ & 242 \\
\hline New Orleans, La__. & $-1,864$ & 223 \\
\hline
\end{tabular}

${ }^{1}$ Turbidity of pure water is 0 . Water with turbidity above 5 should be treated for drinking use.

The water of the Mississippi is relatively clear upstream but becomes turbid in its southerly course, especially at St. Louis, where the Missouri River, "The Big Muddy," enters the main channel. There are similar variations in chemical and physical properties throughout the length of other large rivers, for example, the Ohio and Colorado Rivers.

\section{MINERALS IN SOLUTION}

The source and significance of dissolved minerals are important in understanding water quality. Chemical analysis of water commonly reveals the presence of a surprisingly large number of minerals, most in only trace amounts.

The data reported from a chemical analysis of water may at first seem like a confusing list of numbers. Perhaps this confusion can be clarified; note the following data for water from a river, a well, a canal, and a lake:

\begin{tabular}{|c|c|c|c|c|}
\hline \multirow{2}{*}{ Constituent or property } & \multicolumn{4}{|c|}{$\begin{array}{c}\text { Analyses of water, in parts per million, except } \\
\text { for } \mathrm{pH} \text { and color }\end{array}$} \\
\hline & River 1 & Well 2 & Canal 8 & Lake \\
\hline Silica $\left(\mathrm{SiO}_{2}\right)_{\ldots}$ & 5.4 & 41 & 6.6 & 11 \\
\hline Iron $(\mathrm{Fe})$ & .11 & .04 & .11 & .10 \\
\hline Calcium (Ca) & 9.6 & 50 & 83 & 2.9 \\
\hline Magnesium $(\mathbf{M g})_{-}$ & 2.4 & 4.8 & 6.7 & 9.5 \\
\hline Sodium $(\mathrm{Na}) \ldots$ & 4. 2 & 10 & 12 & 8,690 \\
\hline Potassium (K) & 1.1 & 5.1 & 1.2 & 138 \\
\hline Carbonate $\left(\mathrm{CO}_{3}\right)_{-}$ & 0 & 0 & 0 & 3,010 \\
\hline Bicarbonate & & & & \\
\hline$\left(\mathrm{HCO}_{3}\right)$ & 26 & 172 & 263 & 3,600 \\
\hline Sulfate $\left(\mathrm{SO}_{4}\right)$ & 12 & 8.0 & 5.4 & 10,500 \\
\hline Chloride (Cl) & 5.0 & 5.0 & 20 & 668 \\
\hline Fluoride $(F)$ & .1 & .4 & .2 & - \\
\hline Nitrate $\left(\mathrm{NO}_{3}\right)_{\ldots}$ & 3.2 & 20 & 1.3 & 5.8 \\
\hline Dissolved solids_. _. & 64 & 250 & 310 & 25,000 \\
\hline Hardness _... & 34 & 145 & 235 & 46 \\
\hline Color & 7 & 0 & 97 & 2 \\
\hline $\mathrm{pH}_{\ldots} \ldots \ldots$ & 6.9 & 7.9 & 7.7 & 9.8 \\
\hline
\end{tabular}

1 Stream in Connecticut.

2 Logan County, Colo.

${ }^{3}$ Drainage from the Everglades, Fla.

4 North-central North Dakota.

Let us now consider these constituents and properties both in general terms and with particular reference to the four water analyses. (In the following discussion, some constituents or properties are described that were not reported in the analytical statement.)

Silica $\left(\mathrm{SiO}_{2}\right)$

Silica occurs in sand, quartz, feldspar, and other minerals and is dissolved from practically all rocks. Although many bodies of natural surface water, especially lakes, contain less than 5 ppm of silica, few contain more than $50 \mathrm{ppm}$, and the more common range is from 10 to $30 \mathrm{ppm}$. Well water generally contains more silica than surface water. Of the four samples analyzed, the well water contains $41 \mathrm{ppm}$ of silica and the others range from 5.4 to $11 \mathrm{ppm}$. Silica affects the usefulness of a water because it contributes to the formation of boiler scale; it is removed from feed water for most high-pressure boilers. Silica also forms troublesome deposits on the blades of steam turbines.

\section{Aluminum (Al)}

Aluminum is usually present only in negligible quantities in natural water except in areas where 
the water has been in contact with the more soluble rocks of high-aluminum content such as bauxite and certain shales. Where the organic content of water is high, aluminum frequently occurs as an organic complex in concentrations of $1 \mathrm{ppm}$ or more. Acid water often contains large amounts of aluminum. Aluminum may be troublesome in feed water, for it tends to be deposited as a scale on boiler tubes. It is not shown in the analyses.

\section{Iron $(\mathrm{Fe})$}

Iron is dissolved from many rocks and soils. Ground water may carry several parts per million of iron. Surface water, unless acid, rarely contains more than several tenths of a part per million. Acid water, however, commonly carries relatively large quantities. On exposure to air, iron in nonacid water oxidizes and settles out of solution. In concentrations as low as $0.3 \mathrm{ppm}$, iron causes reddish-brown stains on white porcelain or enameled ware and fixtures and on fabrics washed in the water. None of the four samples analyzed shows iron in significant amounts.

\section{Manganese (Mn)}

Manganese is dissolved in appreciable quantities from rocks in some sections of the country. It resembles iron in its chemical behavior and in its occurrence in natural waters, but is less abundant than iron in rocks. Water impounded in large reservoirs may contain manganese that has been dissolved from the mud on the bottom of the reservoir. Manganese is especially objectionable in water used in laundry work and in textile processing. Concentrations as low as $0.2 \mathrm{ppm}$ may cause a dark-brown or black stain on fabrics and porcelain fixtures. Appreciable quantities of manganese are often found in water containing objectionable quantities of iron.

Calcium ( $\mathrm{Ca}$ ) and Magnesium ( $\mathrm{Mg}$ )

Calcium and magnesium are dissolved from almost all rocks and soils, but the highest concentrations are usually found in water that has been in contact with limestone, dolomite, and gypsum. Calcium and magnesium cause hardness in water and are largely responsible for the formation of boiler scale and deposits in hot-water heaters and pipes and in water systems. Calcium and magnesium are the most universally characteristic constituents of natural water. The analyses of the river and lake waters show the least calcium and magnesium.

\section{Sodium $(\mathrm{Na})$ and Potassium $(\mathrm{K})$}

Sodium and potassium are found in all natural water. Sodium is the predominant cation in some of the more highly mineralized water in the Western United States. Moderate quantities of sodium and potassium have little effect on the usefulness of the water for most purposes, but water that carries more than 50 to $100 \mathrm{ppm}$ of the two chemicals may require careful operation of steam boilers to prevent foaming. More highly mineralized water that contains a large proportion of sodium salts may be unsatisfactory for irrigation. Very high sodium water such as the lake supply would not meet requirements for irrigation use.

\section{Carbonate $\left(\mathrm{CO}_{3}\right)$ and Bicarbonate $\left(\mathrm{HCO}_{3}\right)$}

Carbonate as such is seldom present in natural water. Some water that has been treated with lime contains carbonate. Bicarbonate is formed when carbon dioxide in water reacts with carbonate rocks. Some carbon dioxide is present in rainwater and larger amounts from decaying organic matter are present in percolating water and in lakes and streams. Bicarbonate is the chief anion in a great deal of the earth's natural water and in most of the water used for public supplies. Most water in contact with granite and similar rocks contains less than $50 \mathrm{ppm}$ of bicarbonate, and much water contains less than $25 \mathrm{ppm}$. Water exposed to carbonate rocks may contain as much as 500 ppm of bicarbonate. Carbonate and bicarbonate are reported as alkalinity, which is usually expressed as parts per million calcium carbonate. Because of the very high concentrations of carbonate and bicarbonate in the lakewater sample, the lake would be classed as alkaline.

\section{Sulfate $\left(\mathrm{SO}_{4}\right)$}

Sulfate may be dissolved in large quantities from beds of gypsum and shale. It is formed also by the oxidation of sulfides of iron and occurs in significant quantities in acid mine drainage. Sulfate in water that contains much calcium and magnesium causes the formation of hard scale in steam boilers and may increase the cost of softening the water. The concentrations of sulfate in water from the river, well, and canal are too low to be significant. For the lake water, sulfate 
content is very large, and the sulfate ion is the most dominant ion present.

\section{Chloride $(\mathrm{Cl})$}

Chloride is dissolved from rock materials in all parts of the country. Surface water in the humid regions are usually low in chloride, whereas streams or lakes in arid or semiarid regions may contain several hundred parts per million (see analysis for lake water), especially where the streams receive return drainage from irrigated lands. Sewage increases the chloride content of river water. Drainage from oil wells or other deep wells, salt springs, and industrial wastes may add large quantities of chloride to stream water. Most public supplies from surface sources contain less than $25 \mathrm{ppm}$ of chloride. Large quantities of chloride may affect the industrial use of water by increasing the corrosiveness of water that contains large quantities of calcium and magnesium.

\section{Fluoride (F)}

Fluoride has been reported in some rocks to about the same extent as chloride. However, the quantity of fluoride in natural surface water is ordinarily very small compared to that of chloride. Public health authorities state that the incidence of dental caries is less where there are small amounts of fluoride present in the water supply than where there is none. Fluoride in excessive concentrations, however, is undesirable in water used for drinking. According to a comprehensive report by the California State Water Quality Control Board on water-quality standards, "water containing less than 0.9 to $1.0 \mathrm{mg}$ per 1 [ 0.9 to 1.0 $\mathrm{ppm}]$ of fluoride will seldom cause mottled enamel in children, and for adults concentrations less than 3 or $4 \mathrm{mg}$ per 1 [ 3 or $4 \mathrm{ppm}$ ] are not likely to cause endemic cumulative fluorosis and skeletal effects." The fluoride contents reported in the analyses are below critical values.

\section{Nitiate $\left(\mathrm{NO}_{3}\right)$}

Nitrate in water is considered a final oxidation product of nitrogen-containing matter. Nitrate concentrations of several parts per million may indicate contamination by sewage or other organic matter. The effect of nitrate on industrial use of water is practically negligible; however, many studies by health officers and medical research scientists have shown that excess nitrate in drinking water is a contributing factor or perhaps the main cause of a condition in infants known as methemoglobinemia ("blue babies"). A report published by the National Research Council concludes that a nitrate content in excess of $44 \mathrm{ppm}$ should be regarded as unsafe for infant feeding. None of the four analyses show excessive nitrate.

\section{Phosphate $\left(\mathrm{PO}_{4}\right)$}

Phosphorus is an essential element in the growth of plants and animals, and some sources that contribute nitrate, such as organic wastes and soils, may be important as sources for phosphate in water. The addition of phosphate in water treatment constitutes a possible source, although the dosage is usually small. In some areas, phosphate fertilizers may yield some phosphate to water. A more important source is the extensive use of phosphate in detergents. Domestic and industrial sewage effluents may therefore contain considerable amounts of phosphate.

Boron (B)

Boron occurs as sodium borate (borax) or as calcium borate in mineral deposits and in natural water of southern California. Boron in small quantities has been found essential for plant growth, but irrigation water containing more than $1 \mathrm{ppm}$ boron is detrimental to citrus and other boron-sensitive crops.

\section{Dissolved solids}

Another name for dissolved salts or dissolved mineral constituents in water is "dissolved solids." Most water with less than $500 \mathrm{ppm}$ of dissolved solids-about one-quarter of a level teaspoon of salt in each gallon-is satisfactory for domestic and for some industrial uses. Water containing several thousand parts per million of dissolved solids is sometimes successfully used for irrigation where some of the salts can be removed by the application of large volumes of water on welldrained lands. Generally, however, water containing more than about 2,000 ppm is considered to be unsuitable for long-term irrigation under average conditions. Dissolved solids are sometimes indirectly reported as "specific conductance," a measure of ionic concentration based on the property of natural water to conduct a current of electricity. Excluding the lake water, the dissolved solids reported in the analyses are of moderate concentration. The lake water, however, is about five-sevenths as salty as sea water. 


\section{Trace elements}

Many bodies of natural water contain mineral elements in trace amounts only, so little that they must be reported in parts per billion ( 1 part per billion equals one-thousandth of $1 \mathrm{ppm}$ ). Even so, certain trace or minor elements, as they are sometimes called, are significant to man and to plant life. For example, copper, cobalt, and zinc are believed to be essential to life. Other minerals such as lead, arsenic, and beryllium are known to be toxic to man. The significance of minor elements in human metabolism is not completely understood, despite much research by biochemists, physicians, and public health scientists. Among minor elements needed, within prescribed amounts, for crop production are copper, zinc, and molybdenum.

All water, including all public water supplies, contains minor elements. For example, the treated water delivered to consumers of Kansas City, Mo., has trace amounts of many of these elements. Concentrations are very low and well within the drinking-water standards recommended by the U.S. Public Health Service. The source of the city's water supply is the Missouri River. A sample of Kansas City tap water taken July 26, 1961, showed the following concentrations of some common elements as parts per one billion parts of water:

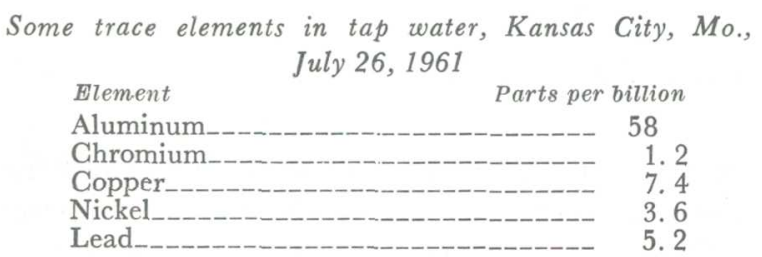

\section{HARDNESS AND OTHER PROPERTIES}

Aside from minerals in solution, many other factors determine the quality of water. Hardness, color, taste and odor, $\mathrm{pH}$ or balance between alkalies and acids, turbidity and temperature (previously noted), for example, also affect water quality.

\section{Hardness}

Hardness is caused almost entirely by compounds of calcium and magnesium. Other constituents-such as iron, manganese, aluminum, barium, strontium, and free acid-also cause hardness, but they usually are not present in quantities large enough to have any appreciable effect.
Hard water contains significant amounts of calcium and magnesium, soft water does not. The Geological Survey classifies hardness according to the following table, in terms of the amount of calcium carbonate (the principal constituent of limestone) or its equivalent that would be formed if the water were evaporated:

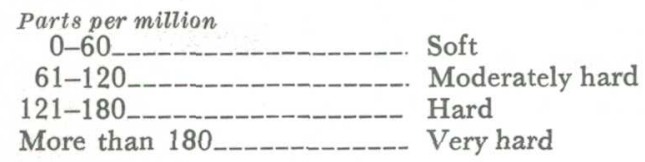

The weighted (according to population) average hardness, by States and Puerto Rico, of water delivered from 1,596 public supplies is shown in figure 4. This study, reported for 1962, classifies the average hardness in selected ranges. Values today would show little, if any, change.

Water that has less than $60 \mathrm{ppm}$ of hardness is usually rated as soft; it is suitable for many purposes without further softening. Water with hardness ranging from 61 to $120 \mathrm{ppm}$ may be considered moderately hard, but this degree of hardness does not seriously interfere with the use of water except in high-pressure steam boilers and in some industrial processes. Water with hardness ranging from 121 to $180 \mathrm{ppm}$ is considered hard, and laundries and industries may profitably soften such supplies. Water with hardness above 180 will probably require some softening before being used for most purposes. However, this classification is only a general guide, for industries vary in their tolerance of hardness. A beverage maker may consider water of $50 \mathrm{ppm}$ satisfactory, whereas a rayon manufacturer would consider the same water hard and unsatisfactory (fig. 5).

Most of us, and especially housewives, are interested in whether water is hard or soft. Hard

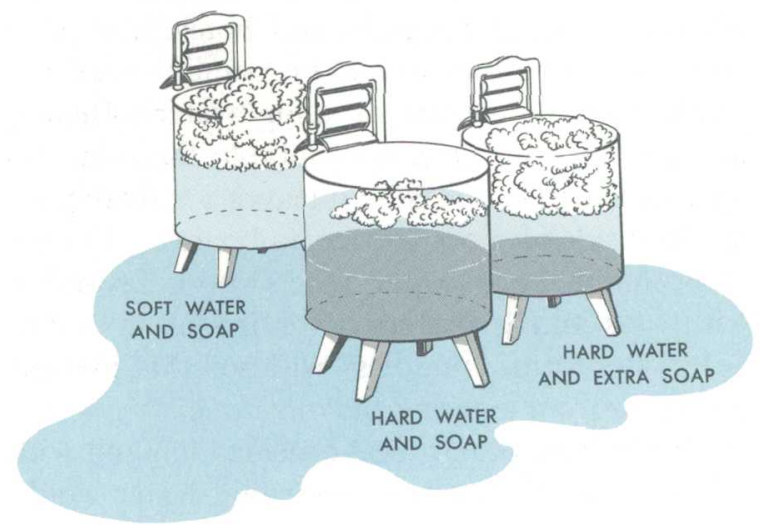




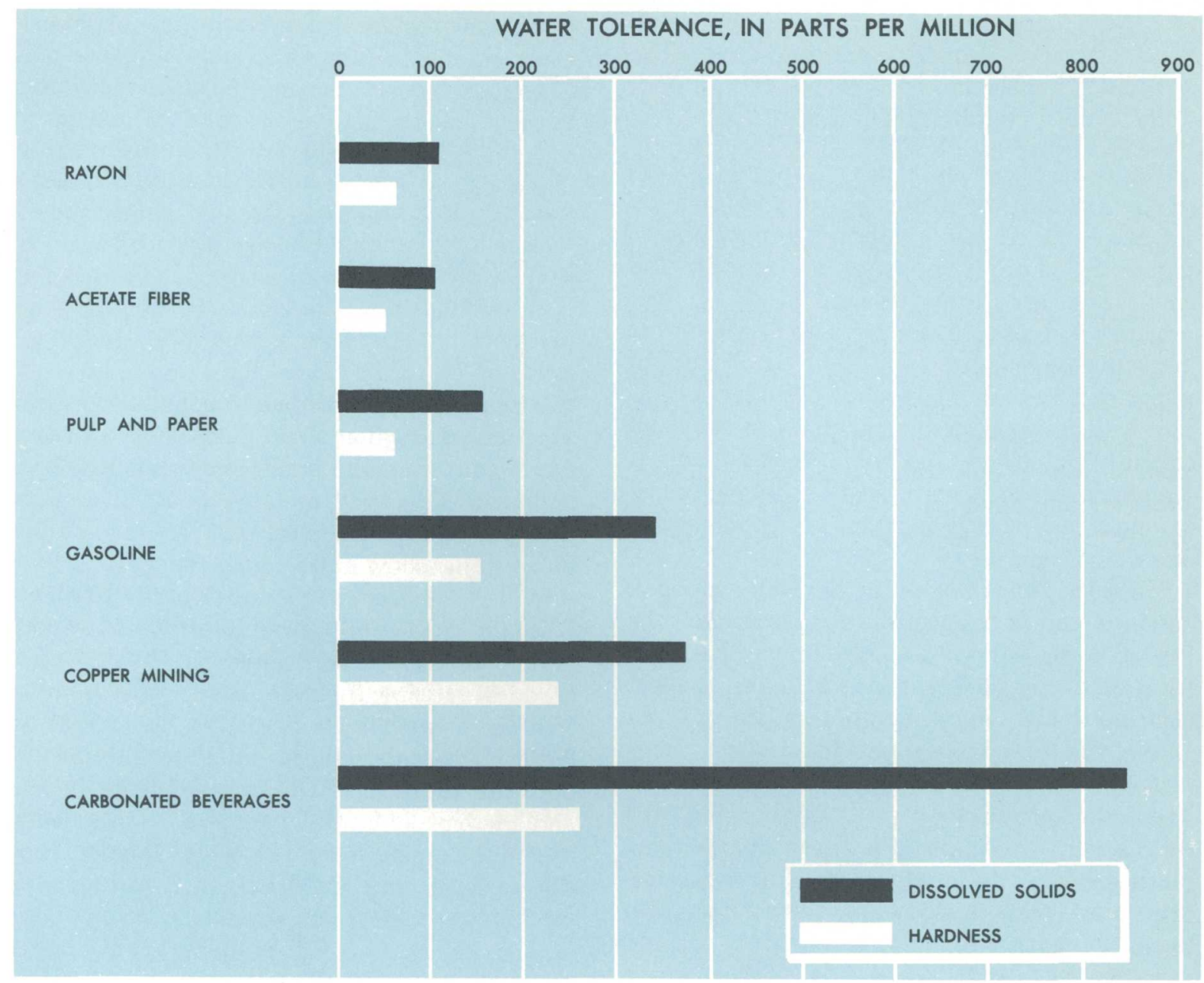

FIGURE 5.-Quality-of-water tolerances for certain industries.

water needs a good deal more soap than soft water to make a good lather. Now that nearly everyone uses detergents, however, that is not the most important problem. Hard water roughens clothes and hands as well. Each year, hard water costs the average American family about $\$ 170$ by shortening fabric life. Homes and institutions such as hospitals and hotels that do a great deal of dishwashing or laundry may actually save money by installing water-softening units. Hard water is not suitable for some industrial processes, because it leaves a scaly deposit on the inside of pipes and steam boilers. On the other hand, hard water reacts more favorably with soils and is preferred for irrigation water. Soft water forms "puddles" with soil that prevent the water from entering the root zone.

On the basis of hardness classification and with reference to the analyses, the canal water would be rated very hard, the well water hard, and the river and lake water soft. The very high salinity (25,000 ppm) of the lake water, however, would retard formation of soap lather.

\section{Color}

In water analysis the term "color" refers to the appearance of water that is free from suspended sediment. Turbid water that appears yellow, red, or brown where viewed in the stream may show very little color after the sediment has been removed. The yellow-to-brown color of some water is usually caused by organic matter extracted from leaves, roots, and plant remains. In some areas, objectionable color in water results from industrial wastes and sewage. Clear deep water may appear blue as the result of a scattering of sunlight by the water molecules. Water for domestic use and some industrial uses should be 
free from any perceptible color. The U.S. Public Health Service's drinking-water standards set the permissible upper limit for color as 15. (This value is not in parts per million but is measured on what is called the platinum-cobalt scale; the test involves comparison of water color with those of standard chemical solutions.) A color of less than 10 generally passes unnoticed. Some swamp water has natural color of 200 to 300 units or more. The color of 97 for the canal water (appearance of tea) is representative of many surface supplies that drain the muck and peat deposits of the Everglades.

Color occurs mostly in surface water. Highly colored water is objectionable for most industrial processes and from an esthetic point of view is unsuitable for drinking water.

\section{Taste and odor}

The senses of taste and odor are closely associated, although the sense of smell is generally much more acute than that of taste. It is easier and sometimes safer to identify odor than taste. Because both measurements are subjective and personal, they lack scientific preciseness. Disagreeable tastes and odors are commonly caused by living microscopic organisms, decaying organic matter, sewage, and industrial-waste products. Highly mineralized water may have a medicinal taste. Distilled water, on the other hand, has a flat taste because it lacks the minerals and dissolved gases which in moderate amounts make water palatable.

\section{Acid and alkali balance}

The balance between acids and alkalies is another natural feature of water that is very important. This balance is known as the $\mathrm{pH}$. A $\mathrm{pH}$ of 7.0 indicates neutral water. Above a $\mathrm{pH}$ of 7 , the water is alkaline; below 7 , it is acid. The extremes are 0 and $14 . \mathrm{A} \mathrm{pH}$ range of 6 to 8 is common for natural fresh water. Sea water has a $\mathrm{pH}$ of about 8 , that is, it is slightly alkaline. Common vinegar has a $\mathrm{pH}$ of 2.4 to 3.4. On the other end of the scale is saturated lime solution which has a $\mathrm{pH}$ of 12.4. Many industrial processes require careful control of the $\mathrm{pH}$ to produce the desired product. Acid water draining an abandoned coal mine may have a $\mathrm{pH}$ value as low as 2 ; this water is actually a sulfuric acid solution which will dissolve metals readily. Natural water having $\mathrm{pH}$ above 9.0, such as the lake water shown in the analyses, is unusual.

\section{Turbidity}

Turbidity or cloudiness is an optical property of water. When a beam of light passes through muddy water, the intensity of the light is reduced. This reduction, caused by the suspended material in the water, is a measure of the water's turbidity. The suspended material may be fine insoluble products, either inorganic such as clay, silt, and sand, or organic such as industrial or domestic wastes. Practically all public water supplies that are filtered are free from noticeable turbidity. Many consumers object to water exceeding $5 \mathrm{ppm}$ turbidity.

\section{Temperature}

Temperature of water is very important because of the tremendous volumes of water used by industry for cooling purposes. Temperature is important also as a major factor in determining the effect of pollution on aquatic life. For example, the resistance of fish to certain pollutants has been shown to vary widely with temperature. Heat as a pollutant of water is discussed in the description of some waste-water problems.

\section{BIOLOGICAL CONSIDERATIONS}

Biological factors are significant in determining the quality of water. According to the Public Health Service, the presence of fecal coliform organisms (Escherichia coli) in a water sample indicates recent and possibly dangerous pollution. Local health agencies require that a specific minimum number (depending upon population served by the system) of water samples from the distribution system be collected and examined for organisms of the coliform group.

Biochemical oxygen demand (BOD) is a measure of the amount of oxygen required to remove waste organic matter from water in the process of decomposition by aerobic (living only in oxygen) bacteria. The waste organic matter is stabilized or made unobjectionable through its decomposition by living bacterial organisms which need oxygen in the water to do their work. BOD provides then an index of the degree of organic pollution of water.

Nature's rivers and streams support a variety of species of aquatic life. Living organisms in natural fresh water range in size from bacteria 
and minute diatoms to large fish. Biologists have observed that the number of species of aquatic life in a given reach of a river does not change significantly with natural changes in the environment. But man-made changes in water quality, such as river pollution, reduce the number of aquatic species. Periodic checks on the number of species, therefore, are a means of assessing the effects of pollution.

\section{ORGANICS, DISSOLVED GASES, AND SEDIMENT}

Organic compounds, dissolved gases, and sediment each influence the quality or characteristics of water. Pesticides and detergents as examples of organic compounds were discussed in the section dealing with waste-water problems. Many more organic complexes, natural or man-contributed, have been identified in rivers and underground water supplies. Phenolic waste discharged from coke ovens and oil refineries is an example. Even very low concentrations of this material impart a disagreeable taste to water. Tastes and odors have been detected from as little as $0.01 \mathrm{ppm}$.

The commonest dissolved gases in natural water include oxygen, nitrogen, carbon dioxide, hydrogen sulfide, methane, oxides of nitrogen, sulfur dioxide, and ammonia. Some of these gases are derived from the atmosphere, and others may come from decaying organic matter, from industrial air pollution, or from the gases issuing from the earth in volcanic regions. The two commonest gases in water are oxygen and carbon dioxide.

Adequate dissolved oxygen (DO) is necessary for the life of fish and other aquatic organisms. Dissolved oxygen is an active agent, moreover, in causing water to be corrosive. In unpolluted waters, oxygen is usually present in amounts of $10 \mathrm{ppm}$ or less. About 3 to $5 \mathrm{ppm}$ is accepted as the lowest limit for support of fish life over a long period of time. Dissolved-oxygen measurements together with the amount of oxygen utilization (biochemical oxygen demand) are used extensively in reaching decisions about the degree of pollution in a water supply.

Carbon dioxide is highly soluble in water and is produced mostly from decomposition of organic matter. A concentration of less than $100 \mathrm{ppm}$ is not likely to produce any taste in water. In fact, beverages like soft drinks and beer are highly charged with carbon dioxide. In solution, carbon dioxide increases the solvent action of water and makes it more corrosive. In high concentrations, dissolved carbon dioxide attacks concrete and cement, hastens the corrosion of iron and steel, and promotes the solution of lead.

Stream-borne sediment is generally regarded as that sediment which is transported by, suspended in, or deposited by water. Turbulence of the water and colloidal (finely divided particles dispersed but not in true solution) action prevent the suspended sediment from settling out immediately. The size distribution of suspended sediment particles affects the manner and rate of travel as well as the settling of sediments. Suspended sediment should not be confused with turbidity, which is an optical property of water.

\section{SALINE WATER}

Much natural water contains dissolved solids in concentrations exceeding 1,000 ppm. Such water is classed as saline. The Geological Survey classifies the degree of salinity of these more mineralized bodies of water as follows:

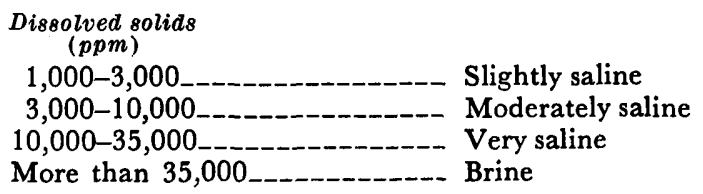

The "slightly saline" group includes many surface-and ground-water-supplies that are used every day or that are potentially usable. The upper limit for very saline water $(35,000 \mathrm{ppm})$ is that for average concentration of ocean water, which is commonly used as a gage in salinity of water. "Brine," in general, represents concentrated ocean water and contains large amounts of sodium chloride-common table salt. Brine such as that in Great Salt Lake, if poured into an ordinary drinking glass and allowed to evaporate, would leave a salt residue 1 inch deep.

Water containing more than 500 ppm of dissolved solids is not considered desirable for domestic supplies, though more highly mineralized water is commonly used where better water is not available. According to the U.S. Public Health Service, more than 100 public supplies in the United States provide water containing in excess of 2,000 ppm of dissolved solids. Many of these supplies are in the southwestern States and in the Great Plains region.

Saline water is denser than fresh water, that is, water dipped from the ocean weighs more, cup 
for cup, than does tap water. Salt water entering a storage reservoir during periods of low inflow is heavier than water near the surface. This heavier water flows along the bottom to the deeper parts of the reservoir and the water in the reservoir is said to stratify-form separate strata or layers depending on differences in salt concentration from top to bottom. Differences in water temperature or sediment concentration also cause stratification. Stratification does not take place in all reservoirs, but occurs, nevertheless, throughout the United States. An example of stratification is seen in Possum Kingdom Reservoir on the Brazos River, Tex. Water released from this reservoir is slightly saline (1,360 ppm dissolvedsolids average for 1961-62). Chloride, an important constituent of the water, varied with depth in one part of the reservoir almost 40 percent according to measurements made March 8, 1962, by the Geological Survey working with the Texas Water Commission. These measurements, reported in the following table, show that the character of the water is fairly uniform in the upper 60 feet but becomes saltier below this depth.

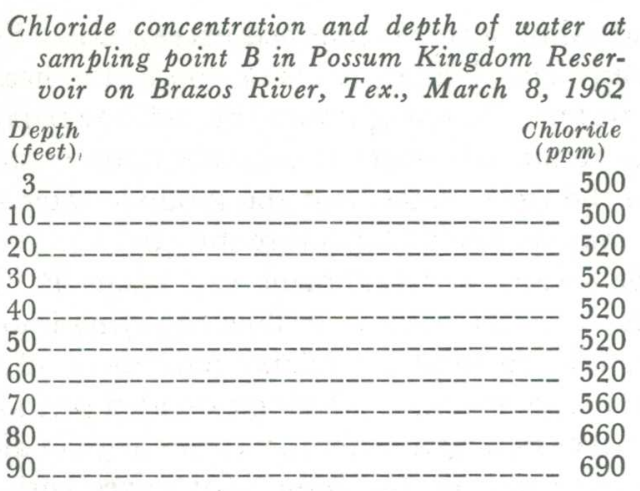

Flood flows, which are much less mineralized than average reservoir water, do not always flush out saline water at depth in a reservoir. During flood flows of 1957 the volume of flood water passing through Possum Kingdom Reservoir was more than three times the reservoir capacity. Yet, saline water was not flushed from the bottom of the reservoir. The storage of flood flows as a means of upgrading the quality of the water becomes less efficient where the most salty water is not flushed out or does not mix with the flood water.

In coastal areas where permeable rocks are in contact with sea water, fresh-water wells may

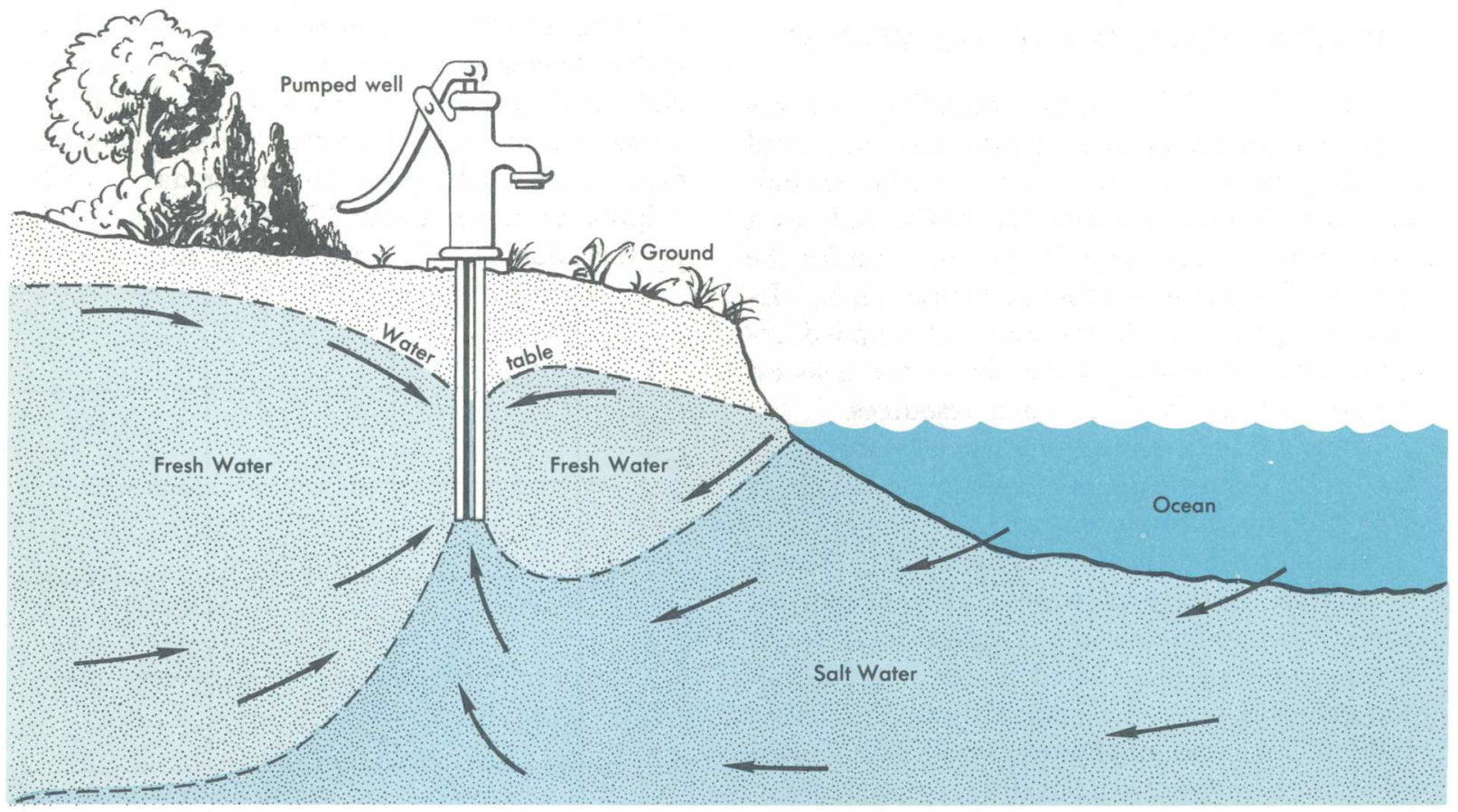

Figure 6.-Relation of fresh water to salt water. 
yield saline water if pumped excessively. Fresh water, being lighter, floats on top of the heavier sea water. Pumping upsets this delicate balance. As a result, salt water encroaches upon or mixes into the fresh water, and the ground water supply may be spoiled for future use (fig. 6).

Salt-water encroachment can occur in tidal rivers. Fresh-water river flow emptying into the ocean is opposed by inland movement of salt water from the sea. During extended periods of low river flow, salt water moves up the river along the river bottom and some of it mixes with the river water. The extent of salt-water intrusion depends upon the relative densities of the waters, the fresh-water runoff, and tidal action. A minimum fresh-water river flow must be maintained through upstream regulation or releases to control or limit the, effects of salt water moving in from the ocean. For the Delaware River, a U.S. Supreme Court decree requires the Delaware River Master to maintain an agreed minimum flow. The River Master carries out the orders of the Court relating to yields, diversions, and releases of river water. Minimum flows are maintained by releasing water from upstream reservoirs at times when flows downstream are low.

\section{WATER DEMAND AND TREATMENT}

Since World War II, an expanding economy and continued population growth have increased the demand for water. Current usage, excluding water power, exceeds 320 billion gallons a day, of which less than 10 percent satisfies the demand for public supplies and rural needs. Irrigation water for farms and self-supplied requirements of industry place by far the heaviest demands on the Nation's water resources.

Many estimates have been made of water needs by 1980; some projections call for as much as 600 billion gallons per day (fig. 7).

Although water demand is increasing, there is no overall shortage of water. The Geological Survey has estimated the average total freshwater supply of the United States as 1,200 billion gallons a day - twice the projected needs for 1980. There is as much water now in the United States as there ever was, but the geographical distribution of water resources is not always convenient. Los Angeles, for example, obtains its water not only from local sources, but also from the Owens River on the east side of the Sierra Nevada,
240 miles away; from Mono Lake, 350 miles distant; and from the Colorado River, 450 miles east. To supplement these sources, plans are underway to tap rivers in the northern part of the State, which is better watered and less populated.

How much water does one need to stay alive? Experts say that a moderately active man in a temperate climate requires 5 to 6 pints of water a day. It takes this much to replace waste losses of the body. More than 2 pints of water are taken in with normal diet or formed in the body by oxidation of food. About 3 pints are consumed as fluids. Body needs are indeed small, but in order to survive, enough water must be present to regulate body temperature, nourish tissues, and aid in metabolism. In ancient times, total daily water requirements for all purposes, including drinking, food preparation, bathing, and washing of clothes may have averaged 3 to 5 gallons a person. Today in urban areas of the United States as much as 60 to 70 gallons of water are used per person each day, on the average, for household and lawn-watering purposes.

Municipal systems not only provide water for the home but also serve industrial, commercial, and public-use (firefighting, parks) outlets. Many industrial plants find it more economical to buy water from the city than to provide individual supplies from wells or reservoirs. Total water delivered-domestic, industrial, commercial, and public-use-divided by population served is a measure of average water use, usually expressed as gallons per capita per day. Philadelphia averages about 175 gallons per capita per day; San Francisco and New Orleans average

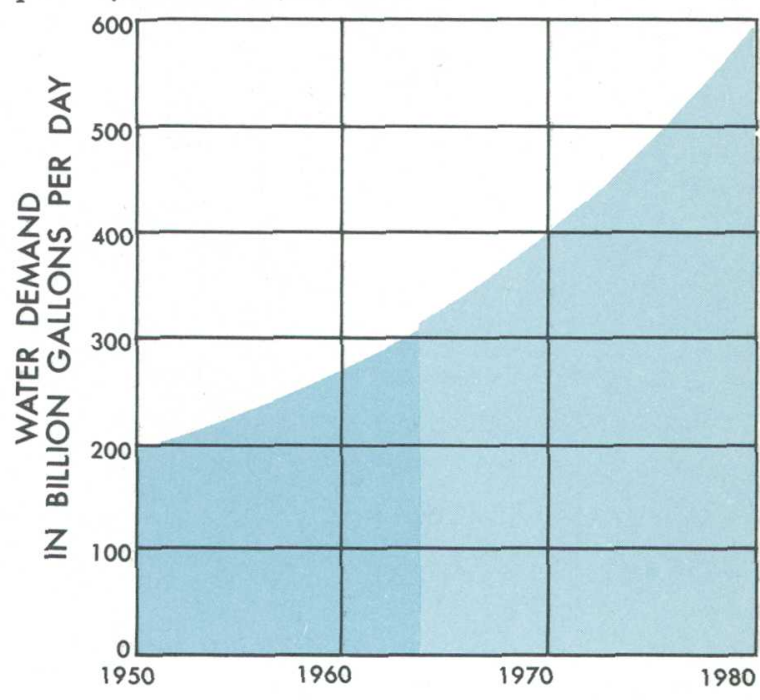

FiguRE 7.-Water demand. 
approximately 94 and 161 gallons per capita per day, respectively. For the United States overall, average individual use is about 160 gallons per day.

The type of industry affects the amount of water used. Compare the water requirements of two American cities, Wheeling, W. Va., and Everett, Wash. Each city serves a population of about 65,000 . Wheeling manufactures chinaware, glass products, hardware, kitchenware, pharmaceuticals, plastics, steel products, textilemill products, tin, tobacco, and wood products. Everett's principal products are wood pulp, paper, plywood, lumber, and shingles. Other industry uses include an ironworks and a stove factory. Wheeling uses an average of 10 million gallons of water a day, whereas Everett uses 100 million gallons daily, 10 times as much as Wheeling. Per capita use of water for Wheeling is 154 gallons a day, and that for Everett, 1,540 gallons.

Everett's high use of water is explained by its pulp and paper industry. Two pulp plants use city water exclusively. A third plant, manufacturing paper, uses the public supply part of the time. Enormous volumes of water are used in this one industry. Average nationwide water requirements for wood-pulp manufacturers range from 10,000 gallons per ton for groundwood pulp to 75,000 gallons per ton for bleached sulfite or sulfate pulp.

Municipalities sometimes have to go to considerable lengths and expense to assure their citizens a sufficient supply of safe, potable water (fig. 8). The quality of the raw intake water largely governs the amount of treatment needed. The water may be chlorinated, aerated, filtered, or softened, or any combination of the four treatments may be used. Very few cities have water supplies of such purity that they do not treat the water at all. However, treatment may range from simple chlorination to elaborate treatment involving six steps or more. Where tests show that water has unpleasant odor and taste, it is treated by aeration-spraying the water into the air so that it is penetrated by oxygen. Then the water is usually "settled," with the help of alum, a fine white powder which forms a gel or curd in water. Impurities stick to the curds of gelantinous alum, as snow sticks to dust particles. The alum "snowflakes" gradually sink to the bottom of the tanks. The water is filtered through beds of sand. Municipal plants use one or all of these methods of treatment.

One of the most modern and efficient watertreatment plants in the world is Philadelphia's Torresdale Plant on the Delaware River, which in 1963 furnished about half of the city's supply. Almost all water-treatment plants operate on much the same principles. Torresdale is probably not typical of the average water-treatment plant, but a description of it will illustrate the extensive treatment of water in the United States.

Torresdale has a maximum capacity of 423 million gallons a day, but normally provides about 282 million gallons of potable water a day. The city of Philadelphia obtains its water from the Delaware and Schuykill Rivers, and the plant was designed to treat badly polluted water. In recent years, however, the combined efforts of city, State, and Federal governments have promoted a great improvement in the degraded condition of the Delaware River.

Like any other river in America today, the Delaware carries many different kinds of matter-from chemicals and detergents to dead vegetation and industrial and animal wastes. Chemicals must be used to burn up the organic matter, to overcome taste and odor, and to control tooth decay and prevent corrosion of metal pipes.

As screened water enters the plant, it flows first into a mixing chamber, where it is given a preliminary chlorine treatment (fig. 9). Then it goes into a large sedimentation basin in which the larger particles sink to the bottom. From there it is pumped to the chemical building where it is treated with chlorine, lime, alum, and carbon. Chlorine destroys organic matter, and the alum settles impurities. Lime helps the formation of alum "snowflakes" and also lessens pipe corrosion. Carbon controls taste and odor. The water is mixed, first rapidly, then slowly. Next it is allowed to settle for $21 / 2$ hours. During this period, alum carries the impurities to the bottom. The water is then filtered through 94 sand beds and receives a final chemical treatment with chlorine, fluorine, and phosphates. Fluorine lessens tooth decay and phosphates reduce pipe corrosion. The plant annually uses more than 13,000 tons of nine common chemicals. The cost of these chemicals varies, but the total is about $\$ 1$ million. The plant itself cost $\$ 25$ million and was 5 years in the building.

Another example of water treatment is in Austin, Tex., which pumps municipal water from 


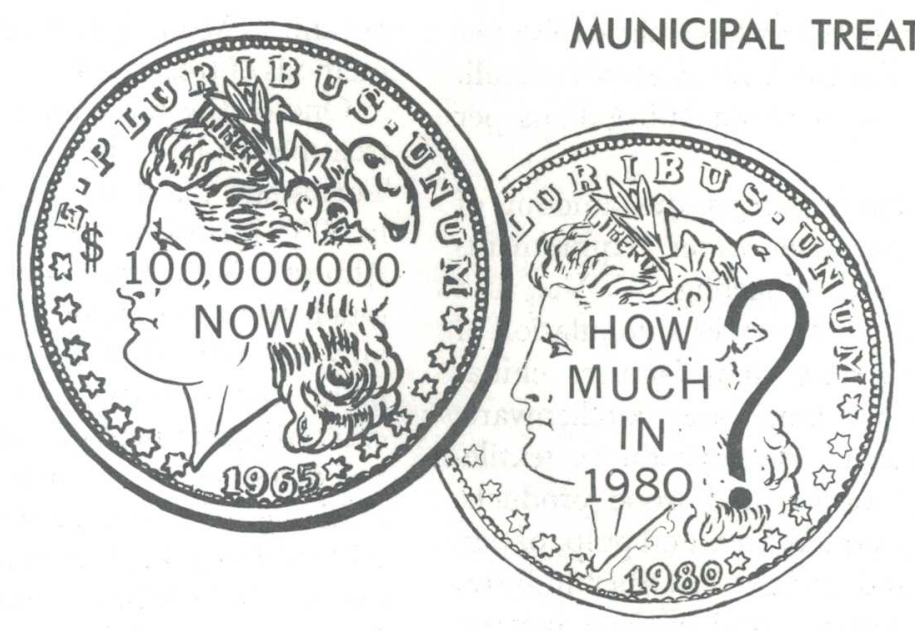

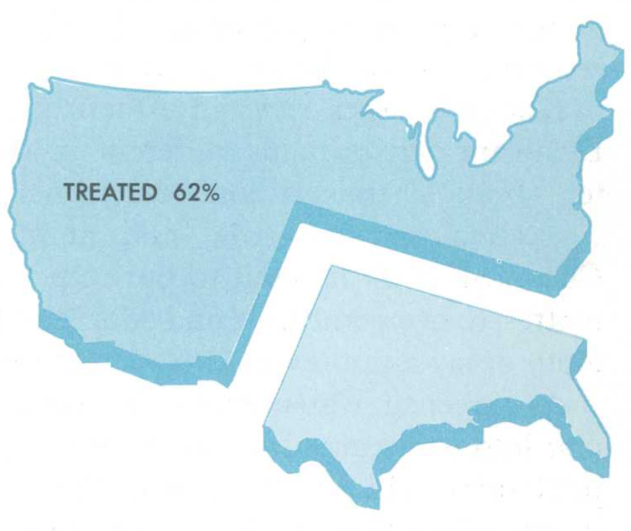

ALL WATER

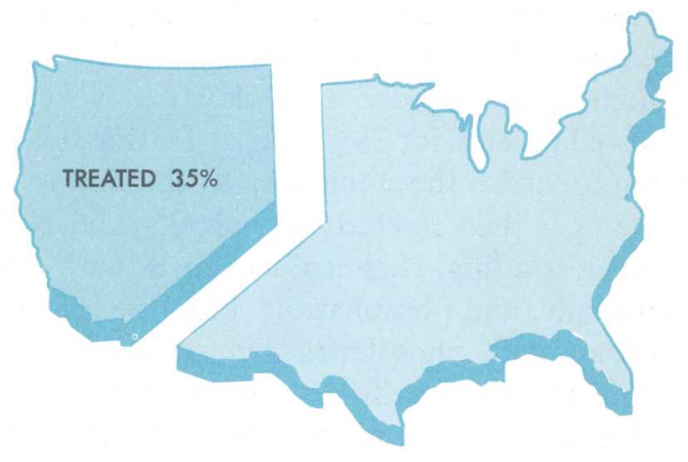

GROUND WATER

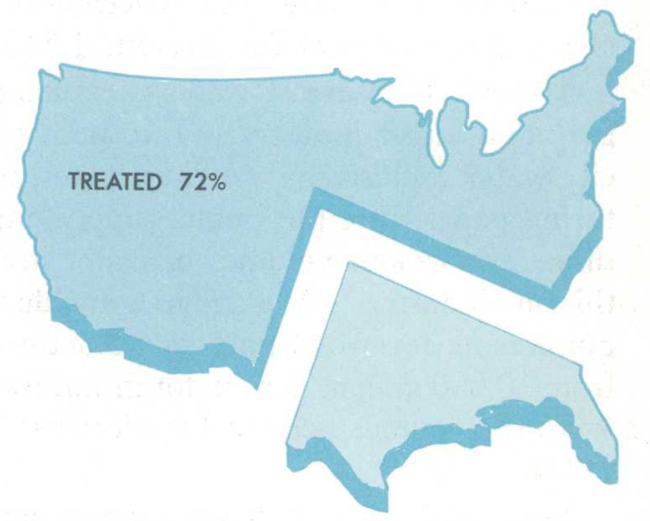

SURFACE WATER

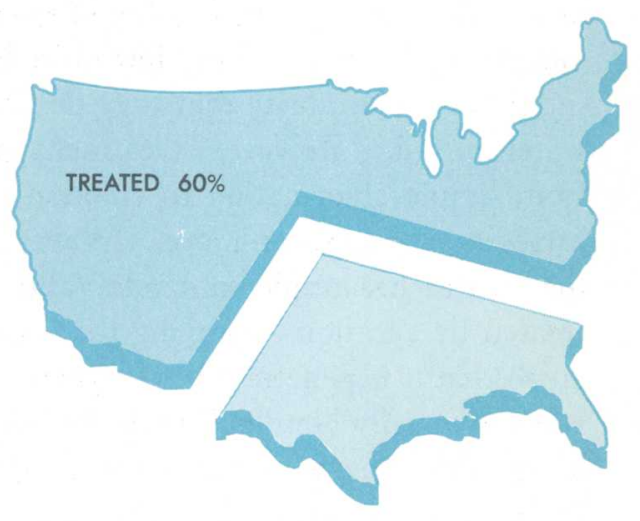

MIXED

Figure 8.-Quality control costs money. 


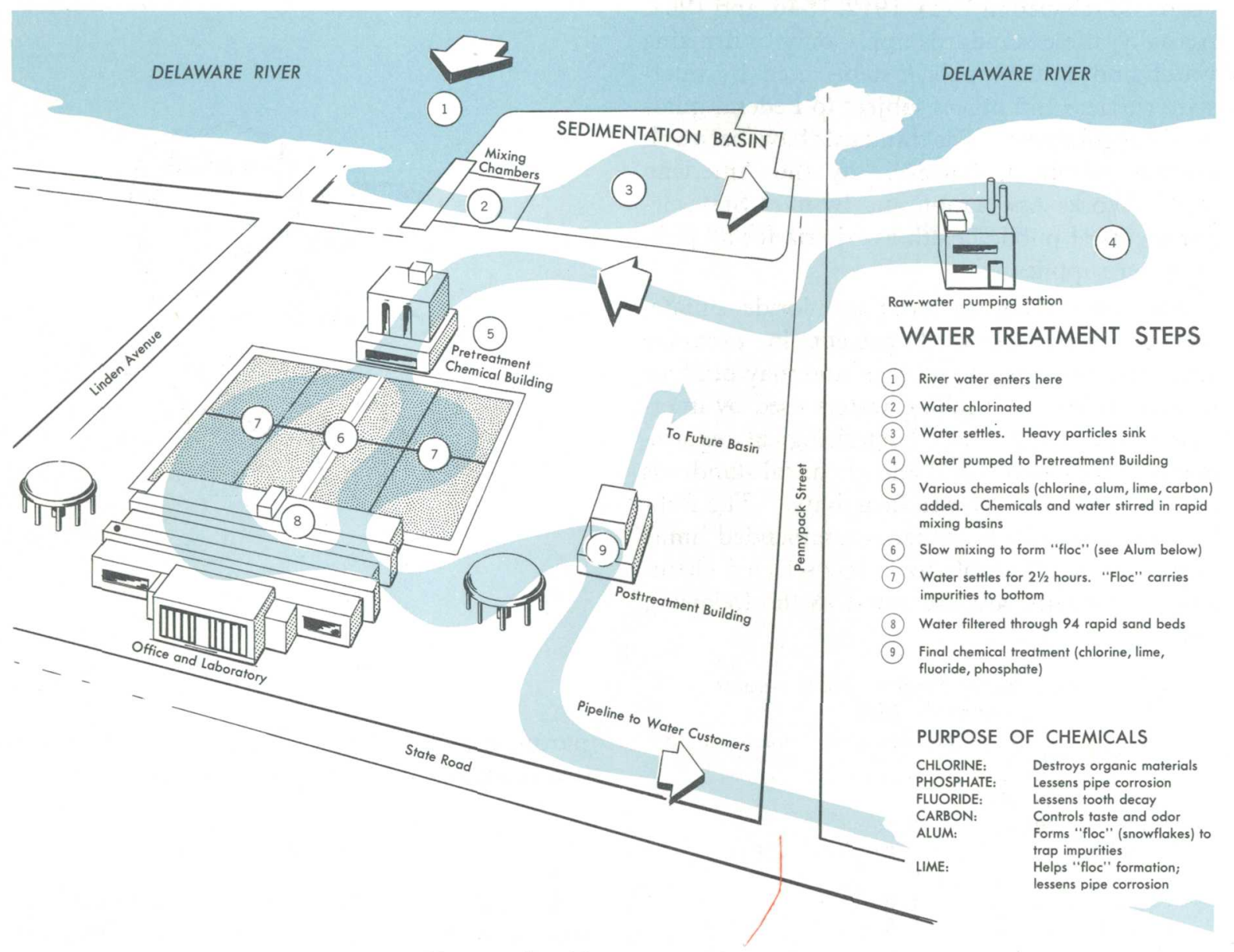

Figure 9.-Treatment of water.

Lake Austin. The lake water is first screened at the intake to remove weeds and leaves and to prevent fish from entering the pumps. Treatment consists of addition of lime, to reduce hardness; iron sulfate, to clump or settle suspended matter, bacteria, and residues from the lime treatment; and chlorine, to destroy bacteria. Finally calgon (a phosphate compound) is added, to reduce pipe corrosion or clogging. Austin watertreatment plant 1 , placed in use in 1954 at a cost of $\$ 3$ million, has a capacity of $33 \mathrm{mgd}$ (million gallons per day); plant 2, originally designed to treat $30 \mathrm{mgd}$,was enlarged in 1963 to a $60-\mathrm{mgd}$ capacity.

In other regions where the raw-water source is a relatively pure mountain stream in a protected watershed, treatment may be limited to application of chlorine and ammonia to destroy bacteria. Water intakes for such cities as Seattle and Tacoma, Wash., and Portland, Oreg., are in such areas where extensive treatment is unnecessary.

\section{CRITERIA FOR WATER QUALITY}

Criteria are helpful in forming a judgment about a water supply-they serve as yardsticks of water quality. Much scientific work has been directed to obtaining or setting criteria for the major beneficial uses of water including domestic, industrial, and agricultural needs. A recent (1963) authoritative publication on water-quality criteria listed 3,827 references and contained 548 letter-size pages of text. Full discussion of criteria even for one beneficial use of water is beyond the scope of this primer. Because the drinking-water standards of the Public Health Service, however, have official status, the reader should become familiar with the general requirements for domestic water supplies.

The Public Health Service drinking-water standards were first adopted and published in 1914 to protect the health of the traveling public. Since that time these standards have been re- 
vised and reissued in 1925, 1942, 1946, and 1962. Actually, these standards apply only to drinking water and water-supply systems used by interstate carriers and others subject to Federal quarantine regulations. The standards have been voluntarily accepted, however, by the American Water Works Association and by most State departments of public health as criteria for all public water supplies.

Such constituents in water as chloride, sulfate, and dissolved solids, if present in excessive amounts, create taste problems and may produce laxative effects. Drinking waters used by interstate carriers must meet bacteriological requirements as well as physical and chemical standards that include criteria for radioactivity. The Public Health standards, either recommended limits or maximum allowable for a few selected chemical constituents, are excerpted in the following table.

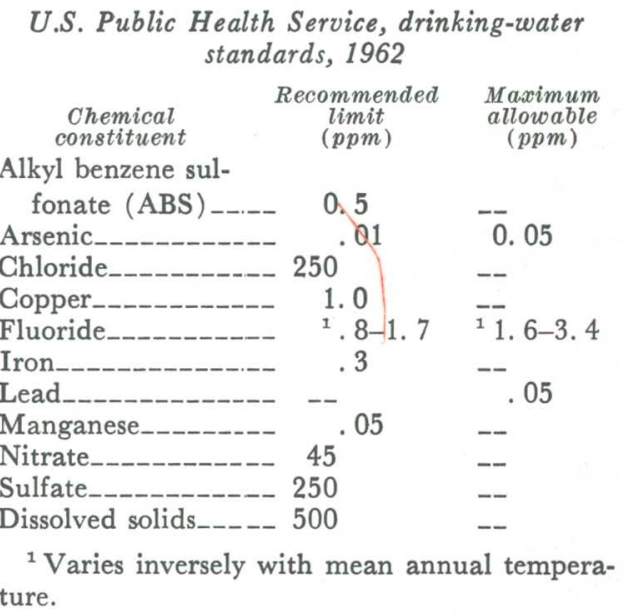

\section{WATER-QUALITY MANAGEMENT}

An adequate supply of water of a quality suitable for use requires good water-quality management. Pollution abatement, improved waste treatment, efficient use of water, recycling of industrial water for reuse, reservoir releases to increase low streamflows, and conversion of salt water to fresh water are some of the most widely used management techniques. Successful management of both water quantity and water quality must be in accord with principles of hydrology-the science of the earth's water.

The pollution abatement accomplishments of the Ohio River Valley Sanitation Commission and the salt-water conversion program of the De-

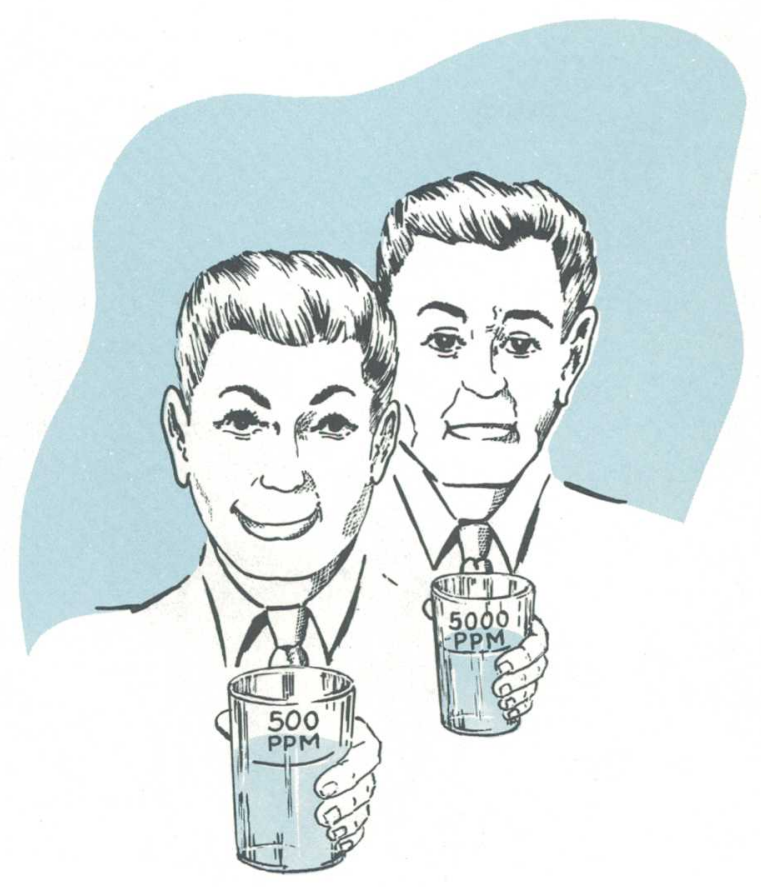

partment of Interior's Office of Saline Water are two examples of water-quality management.

\section{ORSANCO}

In 1948, eight States formed a compact, approved by the Congress, to pool their resources and police powers for control of interstate water pollution on the Ohio River and tributaries.

This new organization was called the Ohio River Valley Sanitation Commission, abbreviated ORSANCO. Conditions prevalent in 1948 showed that more than 99 percent of the people along the thousand miles of river discharged raw sewage. Equally depressing was the lack of interest by industry in providing waste treatment. The Ohio River received industrial wastes which were highly variable in composition and included coke byproducts and wastes from the meat-packing, metal-finishing, coal-mining, dairy, steel, distillery, and tannery industries.

By 1965, ORSANCO has made such progress that treatment plants are in operation or under construction for 94 percent of the valley's 11.4 million sewered population. Further, of the 1,730 industrial plants discharging directly to streams, 90 percent (1,552 plants) have installed facilities that meet basic-control requirements established by ORSANCO. The job is not nearing completion, however. Local conditions of 
gross pollution are still present, and industrial waste control is subject to further refinements. One problem still not wholly resolved is the acid mine-drainage waste in the upper Ohio basin.

\section{DESALINIZATION}

Saline water from wells or the ocean is converted-or "desalinized"-into fresh water in two ways: One process removes the water from the salt, the other removes the salt from the water. Both methods have been studied extensively under Office of Saline Water direction in research laboratories, in pilot units, and in experimental plants. Water is removed by heating or freezing. Salt is taken out by electrodialysis (electrical separation from pure water by a membrane, such as parchment). Production costs have been the determining factors in desalinization, which has not been competitive in costs with delivery from conventional public water-supply systems.

Preliminary data indicate that the distillation plant in Freeport, Tex., will be able to produce fresh water from sea water at a cost of $\$ 1$ to $\$ 1.25$ per 1,000 gallons. The electrodialysis plant at Buckeye, Ariz., when operated at full load 98 percent of the time, is expected to produce drinking water at a cost of 33 cents per 1,000 gallons, including operating and fixed charges. For comparison, consider the rate in Washington, D.C., for water piped to the home. A sliding scale is used in computing charges, but a rate of about 27 cents per thousand gallons is typical for a family of four residing in the suburbs. True comparisons, however, of costs between conventional water plants and desalinization systems must take into consideration expenses of delivering or transporting the water to the point of use. In an address June 20,1962, the Secretary of the Interior observed that success of the program to make saline water fit for use will never be a panacea in itself to the Nation's water problem. but it may be a vital element of the solution.

Water-quality management will receive increased attention in future plans for water development. The privilege of using water only once and then discarding it is becoming more and more a luxury; for truly, "everyone can't live upstream."

\section{THE NEED FOR RESEARCH}

Much research on water quality is carried on in the field and in government, industrial, and academic laboratories. Some organizations engage in research on the origin, control, treatment, and disposal of domestic and industrial wastes in the water environment and on the study of such problems as the occurrence of algae and related organisms in water supplies and the role of water in transmission of viral diseases. Other agencies are investigating the occurrence of iron, manganese, and aluminum in natural water; the natural distribution of radioactive elements in water; the chemical problems involved in artificial recharge of wells; the amounts of minor or trace elements in water supplies; ground-water contamination; the identification of minerals in sediments carried by streams; and the effects of biological life on water quality. These examples are a few of the kinds of research undertaken by scientists and engineers-there are many others. Activities such as the development of analytical methods and techniques, research on means of reducing evaporation from lakes and reservoirs, and study of the effect of streamflow regulation on water quality could be mentioned. Scientists are determining the solubility of minerals in order to predict the chemical character of water in lakes, streams, and ground-water bodies. Research is progressing on the use of isotopes and dyes to trace the movement of water above and below the ground. But there are still many unknowns in an understanding of the behavior of water in the earth's environment, and the processes, reactions, and fundamentals involved in water movement must be well defined before answers to many practical problems can be obtained.

Some areas where more research is needed are: Salt balance of irrigated valleys; waste treatment and water reuse; effect of conservation measures on sediment yields; effects of herbicides, pesticides, and commercial fertilizers on water supplies; effect of higher water temperature on aquatic plants and fish life; effect of surface storage on chemical quality of water; assessment of future water requirements; measurement of sediment bedload. 


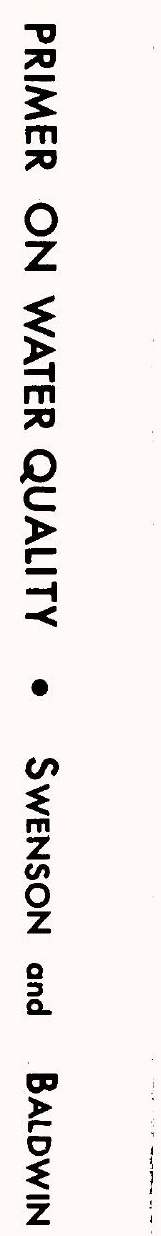

